\title{
A REVOLTA DOS BASTARDOS: do Pentecostalismo ao Bolsonarismo
}

\author{
Mariana Côrtes*
}

\begin{abstract}
O artigo pretende oferecer uma contribuição teórico-metodológica para o debate sobre o neoliberalismo autoritário, a partir da perspectiva das margens, mais especificamente, do movimento pentecostal. Ao traçar uma genealogia da expansão do pentecostalismo durante as três décadas da Nova República, o texto argumenta que algumas dimensões presentes na virada autoritária brasileira foram gestadas nas agências pentecostais, como o diagrama da guerra, a recusa da humilhação, o dispositivo anti-autoridade e a gramática do empreendedorismo. Toma-se como tese central que o pentecostalismo e o bolsonarismo podem ser descritos como uma revolta dos "bastardos". Das margens ao Estado, pretende-se analisar como uma contestação dos indivíduos periféricos que ocupam posições "ambíguas" dentro do campo religioso tem uma conexão com uma insurreição conservadora, que visa alcançar posições institucionais nos poderes legislativo, executivo e judiciário, a partir de sujeitos que ocupavam posições heterodoxas em vários campos de atuação, como o jurídico, o político, o militar, o acadêmico.
\end{abstract}

PALAVRAS-CHAVE: Neoliberalismo autoritário. Pentecostalismo. Bolsonarismo. Recusa da humilhação. Bastardos.

\section{INTRODUÇÃO}

Como contar a história do neoliberalismo a partir das veredas brasileiras? Sob o impacto da vitória eleitoral da extrema direita, devemos tomar fôlego e revisitar as mais de três décadas da nossa Nova República? Escrutinar seus vacilantes passos e suas histórias obscuras, para que enfim possamos desvendar - ou pelo menos ter a coragem de fitar a Górgona (Agamben, 2008) - do monstro que nos avizinha? Ao apostar as fichas no "horizonte de superação" (Telles, 2010), a esquerda brasileira viu o período da redemocratização como uma chance de realizar o projeto de fabricação do universalismo da cidadania. Após o "desmanche neoliberal” dos anos 1990, o ciclo de governos petistas (2002-2016) havia acalentando as esperanças dos movimentos progressistas de que assistíamos a um plano de reparação

* Universidade Federal de Uberlândia. Instituto de Ciências Sociais.

Campus Santa Mônica - Bloco 1H. Alameda das Aroeiras, 2121. Bairro Santa Mônica. Cep: 38400-902. Uberlândia

- Minas Gerais - Brasil. marianampcortes@gmail.com.

https://orcid.org/0000-0002-0679-5524 de injustiças historicamente persistentes. A ascensão de um movimento civil de nova direita a partir de 2013, o golpe parlamentar contra a Dilma Rousseff em 2016 e a eleição presidencial de Jair Bolsonaro em 2018, pegaram parte do pensamento crítico à contrapelo. O bolsonarismo, contudo, não é um acidente histórico. Sua irrupção desconcertante na cena pública é apenas a face espetacularizada de um processo insidioso que se insinua na sociedade brasileira, como um rio subterrâneo, há pelo menos trinta anos. A violência desmesurada que o bolsonarismo inflama, que pode ter sobressaltado parte da intelligentsia nacional, não é, contudo, uma linguagem nova. Sua gramática, feita de carne e sangue, se sedimenta na experiência brasileira há muito. E as margens já sabiam disso. Os homens e mulheres brasileiros, habitantes das periferias das médias e grandes cidades, conhecem essa linguagem. Seu estar-no-mundo é atravessado por um diagrama da guerra, encenado em múltiplas dimensões: o deus bélico do pentecostalismo que trava uma luta diligente contra o mal diabólico (Almeida, 2009; Machado, 2014; Vital da Cunha, 2015; Sant'Ana, 2017); a "sociabilidade violenta" do "mundo do 
crime" e o imperativo de aniquilação do inimigo (Feltran, 2011; Machado da Silva, 2008); as milícias que aterrorizam territórios através da chantagem, da ameaça e do extermínio (Feltran, 2021; Manso, 2020). Se esse diagrama da guerra opera por meios dos dispositivos do pentecostalismo, do crime e das milícias, ele também se traduz na modalidade de uma guerra econômica, que atravessa a todos, convocados a se tornarem "empreendedores de si mesmos", como recurso último de sobrevivência no mercado.

A virada autoritária do neoliberalismo à brasileira é um bicho de mil cabeças e milhares de rabos. E, por isso, exige um esforço coletivo de pesquisa acadêmica, pois é um fenômeno recoberto por uma multicausalidade histórica de difícil apreensão. Ao delimitar um fragmento dessa realidade, muitas hipóteses importantes foram formuladas: a mídia e a fabricação de um sentimento radical de antipetismo; as redes sociais e o agenciamento de notícias falsas; as disputas em torno dos poderes legislativo e executivo; as transformações macroeconômicas causadas pela crise financeira; a dinâmica das lutas de classe e frações de classe; os deslocamentos do jogo de tabuleiros do judiciário; entre outras. As ciências sociais brasileiras vêm se lançando no desafio dessa empreitada heurística, na qual o dossiê em curso procura se inserir ao oferecer contribuições teórico-metodológicas que ambiciona jogar alguma luz sob a opacidade desse fenômeసิ no. Sem pretender esgotar a compreensão do is mesmo, o presente artigo busca oferecer uma Oे hipótese para um dos fios - um entre muitos ๙ิ - que compõe o emaranhado novelo do chaホi mado "bolsonarismo", cujo modus operandi $\stackrel{2}{2}$ pretende ser debulhado aqui sob a perspectiva ङे das margens, mais especificamente, sob a mi-

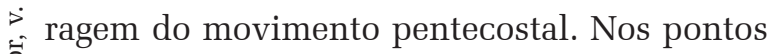
de fricção entre Estado e margens, neoliberalismo e pentecostalismo, como veremos, produziu-se uma tecnologia social inventiva de governo das condutas dos sujeitos periféricos, que guarda uma conexão estreita com a ascensão da nova direita e sua guinada autoritária.
Como demonstrou Aishwa Ong (2006), o neoliberalismo não se insere nos países como um "tsunami econômico e autoritário" que encharca espaços previamente vazios (Almeida, Andrade \& Côrtes, 2021). Ao operar por meio de uma máquina polimórfica, a racionalidade neoliberal se articula, em híbridos propositadamente impuros, com racionalidades políticas que a precedem, que incorporam sua lógica ao mesmo tempo que a modificam, em um processo de retroalimentação incessante. No Brasil, a racionalidade neoliberal, quando chega, encontra - ao mesmo que tempo que produz - uma configuração social previamente estabelecida. Ao se conjugar com essa última, a governamentalidade neoliberal incita a co-fabricação de estranhas combinações, que agora estamos em condições de delinear sua inusitada arquitetura. Mundo do crime, organizações milicianas e movimento pentecostal compõem esse caleidoscópio multifacetado. Portanto, olhar o fenômeno do neoliberalismo autoritário e seu resultado mais bem-acabado, o bolsonarismo, pelas margens, impõe o desafio de narrar uma história que começa antes dele, nas formações societárias que se gestavam nas periferias do capitalismo à brasileira. Mirar retrospectivamente para essa história implica também admitir o que não fomos capazes de ver, quais eram os pontos-cegos que haviam nos escapado.

\section{PENTECOSTALISMO: Uma história das margens}

Durante a última década do século passado, no contexto da redemocratização, tem-se a primeira rodada de neoliberalização no Brasil, com a inserção da economia nacional no mercado global e as reformas gerenciais nas empresas e no Estado, sob o impacto do "choque de gestão" do new management e a difusão de um novo modo de subjetividade no mundo corporativo privado e público (Andrade, 2019a; 2019b), que tem no empresário de si 
mesmo, e não no parceiro da troca, o emergente modelo de homo oechonomicus (Foucault, 2008a, 2008b; Dardot \& Laval, 2016). No contexto das periferias brasileiras, assiste-se ao deslocamento da questão social que impactou o modo de vida dos habitantes das margens. Nos enclaves urbanos que haviam sido estruturados em torno de influxos de industrialização das décadas de 1970/1980, como é o caso da metrópole de São Paulo, as políticas neoliberais, e a radicalização de processos de precarização do mercado de trabalho, fazia-se sentir nos horizontes das famílias: a estabilidade do emprego fordista cedia lugar ao desemprego e/ou ao subemprego; a criminalidade violenta tornava-se uma alternativa possível para jovens que viram suas perspectivas de futuro fraturadas; setores progressistas da Igreja Católica (articulados em torno da Teologia da Libertação e das Comunidades Eclesiais de Base) saíam de cena ao passo que proliferavam por todos os cantos igrejas pentecostais (Feltran, 2014; Côrtes, Jardim \& Miagusko, 2018). Os então "novos" - agora velhos - personagens dos anos 1970/1980 (Sader, 2001) saíam de cena para que novos personagens assumissem seu lugar. Ao invés de padres católicos de esquerda, operários industriais sindicalizados, membros de associação de moradores, intelectuais orgânicos do Partido dos Trabalhadores, outros personagens ocupavam a cena urbana: traficantes de drogas do baixo escalão, "viradores" do trabalho informal, desempregados por desalento (Jardim, 2009), pregadores pentecostais.

Nos estudos das ciências sociais da religião, tratava-se de investigar as razões da perda do monopólio católico na oferta de bens de salvação (Pierucci \& Prandi, 1996) e do crescimento impressionante dos evangélicos, que haviam saltado de 9,0\% no início da década de 1990 para atingir o número de 15,4\% em 2000, segundo dados do Censo do IBGE. Ante a perplexidade da expansão evangélica, encarrilhada pelo movimento pentecostal/neopentecostal, parte dos pesquisadores formularam o seguinte diagnóstico: a ênfase na oferta de soluções mágicas para problemas urgentes (desemprego, doença, decepção afetiva) era um signo inequívoco do atraso brasileiro. A remagificação do religioso, a democratização do êxtase e a exacerbação do emocional eram sintomas claros de que o Brasil não havia concluído o processo de secularização (Pierucci \& Prandi, 1996). Contudo, ao revisitar essa hipótese, mais de vinte anos depois, observa-se que o tema da secularização incompleta acaba por reproduzir, talvez não intencionalmente, uma das "armadilhas epistemológicas" (Abílio, 2020) mais persistentes das interpretações sobre o Brasil: a ideia de uma dualidade entre modernização e atraso, aqui, nos termos da oposição entre secularização e magia. O argumento de que nos anos 90 estruturava-se uma espécie de "pronto-socorro" mágico para desesperados, sinal de nossa inoperância civilizacional, contribuía para esclarecer o fenômeno do boom pentecostal ao mesmo tempo que obscurecia parte do que estava acontecendo. Era um dos nosso pontos-cegos. Outra coisa também estava se delineando, ainda insondável, cuja investigação ainda estaria por vir.

O movimento pentecostal se expandia nas periferias das cidades, em múltiplas configurações: 1) megatemplos neopentecostais, próximas a pontos de ônibus, em largas avenidas, com intensa circulação de pedestres, em busca de uma população flutuante (Almeida, 2009); 2) denominações consolidadas que se inseriam nas redes de vizinhança compondo congregações estáveis de fieis; 3) e igrejas que pareciam nascer do dia para noite, resultados de dissidências imprevistas e empreitadas privadas de pastores autônomos, que alugavam uma sala comercial onde antes havia sido um boteco, uma padaria ou um salão de cabelereiros, e criavam um novo nome para seu estabelecimento religioso, na pretensão de que seus cultos, mais do que os dos concorrentes, encontravam-se encharcados da unção de Espírito Santo. Além do espaço eclesiástico-congregacional das igrejas que se espalhavam nos espaços periféricos, observou-se a intensifica- 
ção da formação de uma indústria pentecostal de bens e serviços simbólicos. Gestava-se um comércio pulsante e diverso no qual se vendia livros, roupas, objetos ligados ao mundo cristão; canções gospel com ritmos musicais de todos os tipos; pregações espetaculares de missionários-celebridades; e testemunhos de "pregadores-itinerantes" que narravam os horrores de sua biografia pregressa como "ex-bandido", "ex-mendigo", "ex-bruxo", "ex-deficiente", "ex-prostituta", e uma infinidade de outros "ex" (Côrtes, 2007; 2017). Durante a primeira onda do processo de neoliberalização no Brasil (Andrade, 2019a; 2019b), o pentecostalismo criava um inventivo mercado informal de trabalho religioso, que incorporava cantores gospel; missionários-celebridade; pregadores autônomos que abriam igrejas por sua própria conta e risco; e pregadores pauperizados que tinham como único trunfo oferecer sua condição de precariedade (e desesperos recorrentes) como mercadoria simbólica. Por meio de um círculo vicioso que se retroalimentava, um mercado emergente (e improvisado) de trabalho religioso incorporava uma parcela dos sujeitos periféricos que o mercado formal de trabalho secular rejeitava. Os sujeitos refugados do "desmanche" neoliberal encontravam possibilidades de inserção social na "viração" pentecostal, em um capitalismo pentecostal à brasileira. As políticas neoliberais impunham processos de precarização, e os sujeitos periféন ricos, por meio da sua própria agência - uma N agência dos governados - encontravam soluções para a precarização, o que produzia, em última instância, uma defesa do mercado, ainda na forma inaudita de um mercado pen¿ tecostal da "ralé." Paradoxalmente, a mesma fi grade de inteligibilidade econômica (a concorrência) que os havia expulsado do campo da formalidade, agora era reabilitada na promoção de uma competição entre pobres e miseráveis pentecostais, em uma disputa para ver quem mobilizava de forma mais competente as atrocidades de sua própria história de "refugado" no mercado de pregações e testemu- nhos, em um jogo em que a narrativa mais infame era frequentemente também a mais venal. Assim, o pentecostalismo não representava apenas um processo de "remagificação" do religioso, que comprometia nossa vacilante jornada rumo à aguardada secularização, mas fabricava uma tecnologia social altamente inventiva de governo das condutas. Essa não oferecia apenas saídas milagrosas para angústias mundanas, mas formatava um novo mercado material e um novo diagrama simbólico, tanto nos espaços congregacionais como nas modalidades de trabalho religioso, em que os sujeitos periféricos podiam traduzir, em linguagem eclesiástica, teológica e soteriológica, quais eram os seus lugares sociais de classe/ raça/gênero, e como se situavam nas margens do neoliberalismo brasileiro.

\section{O DIAGRAMA DA GUERRA}

Se o movimento pentecostal não podia ser caracterizado simplesmente como um "pronto-socorro mágico" ou uma espécie de "supermercado da fé", como o poderíamos caracterizar? Quais são as especificidades do seu modus operandi? O que o fez torna-se uma tecnologia social surpreendentemente criativa para os indivíduos à margem? Por que o pentecostalismo parece ter assumido esse lugar melhor do que qualquer outra agência? E como podemos traçar, agora retrospectivamente, as linhas que conectam o movimento pentecostal a nosso torvelinho autoritário? Essas são as questões que movem a presente reflexão. Para tentar respondê-las, tornou-se para mim urgente revisitar, mais de vinte anos depois, o trabalho de campo que realizei durante o curso de graduação nos anos 2000 e 2001 e durante o mestrado de 2002 a 2004. Em uma disciplina da graduação em Ciências Sociais, após ler o artigo Drogas e símbolos: redes de solidariedade em contextos de violência de Clara Mafra, publicado em 1998 no livro Um século de favela, pioneiro na proposta de investigar as relações entre religião e 
violência nas comunidades cariocas, a ideia de pesquisar as conexões entre pentecostalismo e crime se tornou um projeto consistente. Durante a realização do trabalho de conclusão do curso de graduação, esquadrinhei, em um velho Uno Mille verde oliva, todas ruas da cidade de Uberlândia na tarefa hercúlea - quase estúpida em sua arrogância juvenil - de mapear as instituições religiosas da cidade. Sem poder prever esse resultado, constatei que os bairros periféricos que apresentavam os maiores índices de tráfico de drogas e violência contra a pessoa (taxa de homicídios) eram também os espaços urbanos nos quais se notava uma presença massiva, quase ostensiva, de igrejas pentecostais, como se brotassem, ex-hinilo, em cada esquina ou meio de quarteirão, na disputa de espaços com outros estabelecimentos residenciais e comerciais. De onde vinha tanta igreja? Era a pergunta que eu me fazia à época. E por que elas surgiram nesses bairros? Em seu estudo no morro Santa Marta, no fim da década de 1990, Clara Mafra ensaiava algumas hipóteses: o discurso dos "crentes" e dos "bandidos", ainda que opostos quanto a questões substantivas, eram atravessados pelas mesmas formas: "maniqueístas, clientelistas, hierárquicas” (Mafra, 2006, p. 289). Assim, "a continuidade entre os dois sistemas simbólicos propiciaria o crescimento de um no outro" (Ibidem, p. 289). E acrescentava: "Uns são violentos pelo uso da arma, outros, pelo uso da palavra dogmática” (Ibidem, p. 289). Ainda assim, ela advertia, havia uma "fragilidade" nessa "linha de argumentação", pois ignorava a diferença entre os dois planos metafísicos: se "os 'bandidos' afirmavam o poder da 'arma', os crentes afirmavam que sua 'arma' é a Palavra” (Ibidem, p. 289).

Nas franjas da introdução das políticas neoliberais, pentecostalismo e crime disputavam entre si a condução das condutas dos habitantes das periferias das médias e grandes cidades. Em artigo de 2014, Gabriel Feltran argumenta que a derrocada do universalismo da cidadania, no período pós-redemocratização, havia ensejado uma espécie de governo sele- tivo que cortava a população segundo critérios de vulnerabilidade e perigo, dirigindo a cada recorte populacional uma política setorizada destinada a gerir - mas nunca de fato resolver - uma urgência localizada. Quando o Estado abandona qualquer sonho de planificar o povo rumo a um telos civilizatório ou a uma escatologia emancipatória (Foucault, 2008b), e assume, sem culpa nem pejo, que a prerrogativa da arte de governar, segundo a racionalidade neoliberal, é administrar a população por meio de cesuras biopolíticas, tem-se como resultado a abertura do campo para a criação de novas formas de "governamentalidade" (Foucault, 2008a, 2008b). Para Feltran (2014), no contexto brasileiro, ao lado das políticas estatais, dois novos "regimes normativos" se colocavam como governo das margens (e pelas margens): o "mundo do crime" e as agências pentecostais, que passam a oferecer, a seu turno, formas de administração da sobrevivência, da vida, e do limite, da morte. Nas voltas de carro pelos bairros periféricos de Uberlândia-MG; no morro de Santa Marta, pela acuidade inaugural de Clara Mafra (1998); na pesquisa de Vital da Cunha (2015) sobre os traficantes evangélicos na favela de Acari, no estudo de Carly Machado sobre o trabalho de "resgate de bandidos" na Baixada Fluminense (2014), observava-se os dois "regimes normativos" se constituindo, um perante o outro, um contra o outro, mas irremediavelmente atados entre si. E sua linguagem já era a da guerra.

Em 2003, durante minha pesquisa de mestrado (Côrtes, 2007), liguei para o telefone de contato disponível na contracapa de uma fita-cassete onde estava registrada o "testemunho" de transformação de vida e "aceitação de Jesus Cristo" de Marcelinho, "ex-traficante de drogas". Havia adquirido o "testemunho" de Marcelinho na Rua Conde de Sarzedas, no bairro Liberdade, no Centro de São Paulo, onde funciona um dos maiores centros comerciais de produtos e serviços evangélicos da América Latina. Marcelinho atendeu o telefone provavelmente na espera que fosse o conta- 
to de algum pastor interessado em convidá-lo para "dar seu testemunho" em alguma igreja ou evento evangélico. Talvez, com algum desapontamento por não ser esse o caso, Marcelinho topou conversar comigo. Perguntei onde poderíamos encontrar e ele respondeu, com quase nenhuma vacilação: "No cemitério de Perus". Do interior de Minas Gerais, estrangeira aos meandros urbanos do monstro que me parecia a cidade de São Paulo, e sua região metropolitana, lembro-me do sentimento ambivalente que sua resposta me provocou, incapaz de se decidir entre curiosidade antropológica e medo provinciano. Durante a viagem de trem da Estação da Luz até a Estação de Perus, tentava antecipar, sem sucesso, quais eram os conteúdos escondidos da escolha inusitada de Marcelinho. No cemitério de Perus, situado em uma colina, eu e Marcelinho, conversamos, de pé, por quase três horas. Ele contou-me sobre a desagregação da sua família; o abandono da mãe; a infância em um lixão; a dependência química; o ingresso na "macumbaria"; a inserção no tráfico de drogas; a contaminação com o vírus da Aids; as entradas e saídas no sistema prisional; a experiência de quase morte em uma chacina na qual morreram doze pessoas; o ataque de "rivais" no qual recebeu doze tiros no corpo, três na cabeça, saídos de um "revólver preto de cabo branco", tal qual anunciado na revelação de uma pastora. Durante toda a narrativa, à medida que Marcelinho mencioخิ nava amigos de infância e colegas de escola is que, como ele, também tiveram trajetórias biográficas marcadas com a experiência no crime, Marcelinho olhava para mim e, entre inホi tervalos curtos e compassados, apontava para ¿. os túmulos do cemitério, e me dizia, em um கீ misto de resignação e (quase) vergonha: "Josué $>$ está aqui”, "Pedrinho está aqui”, "Alemão está aqui”. Cheia (também) de vergonha, mal conseguia olhar para as covas. Naquelas covas não habitavam mais corpos abstratos e desencarnados. Elas tinham nomes.

A narrativa de Marcelinho era encharcada de referências ao diabo, que ganhava um protagonismo acachapante. Em seu testemunho, permeado de tanto horror e iniquidade, Marcelinho, objeto e sujeito da sua história, vítima e algoz, parecia não conseguir se situar como um sujeito ético, autocentrado e autorreferente. Ao contrário, ao fazer encenar o diabo como o grande demiurgo por trás de suas ações, Marcelinho admitia-se como alguém que havia sido usurpado da própria vontade e responsabilidade, tomado por uma entidade metafísica capaz de exercer o mal. Marcelinho havia vivido (e perpetrado) a guerra, e o diabo era sua tradução. Mas não apenas ele. O Deus acionado no "testemunho" de Marcelinho era também um Deus da guerra. Em uma das minhas primeiras incursões etnográficas pela Rua Conde de Sarzedas, observei uma ausência desconcertante. Embora o nome de Jesus aparecesse gravado em camisetas camufladas com as encantações mágico-bélicas como "Exército de Jesus", "Sangue de Jesus tem poder", "Jesus é meu Senhor", a "ética universalista da fraternidade" (Weber, 1982, p. 379) da prédica cristã estava praticamente ausente. Quase como se o sacrifício último de Jesus Cristo, como o derradeiro cordeiro que lava os pecados do mundo, e entrega aos homens, como pura dádiva, o universalismo da graça, não fosse mais simbolicamente eficaz como teodiceia daquela experiência de mundo. Em sua tese célebre, Max Weber (1982, p. 381) havia demonstrando que a "renúncia" puritana do "universalismo do amor" era a condição para a introdução, por meio da Teologia da Predestinação, de um princípio de seleção, que moveria os indivíduos na "caçada sem descanso" do espírito do capitalismo. O paradigma da seleção (movido pela incerteza da graça) mobilizaria os homens numa sanha inveterada pela busca de signos externos da própria eleição. Na experiência de parte dos sujeitos das periferias brasileiras, o dispositivo da seleção não se sedimentava na concorrência do mundo racional do trabalho industrial/corporativo, engatilhado pela revolução calvinista. Em outra perspectiva, a sina da seleção encontrava-se 
em uma guerra urbana, cravada no corpo, na pele, no sangue, no lixo, no vírus, na droga injetável, na bala, na ameaça de morte iminente, nas batalhas contra inimigos, no extermínio da violência estatal. Enfim, no risco de andar no fio da navalha entre o humano e o não-humano, a vida e a não-vida (Agamben, 2008). Aqui, o princípio da seleção se fez guerra. Ainda que o momento dramático da conversão religiosa seja recoberto pelo transe místico da aceitação de Jesus Cristo como "único e pessoal salvador”, a prédica emissária cristã não tinha lugar, a não ser como invocação mágico-bélica. Nesse mundo, parecia haver espaço apenas para Deus ou o diabo. Não qualquer Deus, mas o Deus dos Exércitos, pronto para se prestar a múltiplas metáforas, como vi nas performances dos ex-bandidos pregadores em igrejas ou eventos. Na conversão religiosa, o revólver 38 era substituído por uma nova arma: a bíblia, com 66 calibres (em referência ao número de capítulos da bíblia protestante). A passagem da violência à teologia parecia ser feita sem qualquer mediação, como se uma linguagem se deslizasse automaticamente sobre a outra, sem dó. O dispositivo velho-testamentário do Deus beligerante, reencenado nos experimentos das margens brasileiras, sob as narrativas pentecostais da luta entre o bem e o mal, será alguns anos depois acionado no ascetismo teológico-militar do "bolsonarismo". A guerra no pentecostalismo era também outro dos nossos pontos-cegos.

\section{MANCOS}

A revisitação do diagrama da guerra nas pesquisas de campo com os ex-bandidos pregadores me fez pensar então o que não tínhamos visto inteiramente, o que se encontrava no "ponto-cego" da abordagem epistemológica das ciências sociais brasileiras naquele momento. Entre os anos de 2015 a 2020, realizamos uma pesquisa empírica nas ocupações das periferias de Uberlândia-MG (Senna \& Swatowiski,
2019). Em uma dessas ocupações, em 2018, entrevistamos um pastor que havia aberto um espaço de culto, que dificilmente poderia ser distinguido do espaço da casa, no terreno em que ele havia ocupado e estava morando desde então. A "igreja” tinha um púlpito elevado acima do rés do chão, cartazes com passagens bíblicas, cadeiras de plástico brancas, paredes compostas de compensados de madeira, mas não tinha um nome. Como diretriz do Movimento dos Trabalhadores Sem Teto, os terrenos podiam ser destinados para a construção de residências, mas não de organizações religiosas. De forma improvisada, pelas beiradas, o pastor Marcos contrariava essa orientação política e celebrava cultos esporádicos no seu templo/ casa. Em uma entrevista que durou cerca de três horas e meia, ele nos contou sua trajetória de vida, que se mistura com a história do pentecostalismo brasileiro. Marcos nasceu em Montes Claros, no Norte de Minas Gerais. Na década de 1970, teve sua primeira experiência com a mística pentecostal ao presenciar o culto de um pregador da Igreja do Evangelho Quadrangular ${ }^{1}$, em que assistiu paredões de "gente endemonhiada" cair ao seu lado e o derrubar no chão. O movimento pentecostal fazia sua irrupção disruptiva e carismática no cenário até então majoritariamente católico do Norte de Minas. Em outros cultos, Marcos viu pessoas vomitando "bolos de cabelo" e bichos estranhos, "uns bichão feio desse tamanho, bicho mesmo, parecendo bicho de toucinho, mas grande, e eu nunca tinha visto um negócio daquele (...), aí eu ficava olhando saindo da boca da pessoa, aqueles trem caindo lá no chão e andando". Anos depois, converteu-se para o pentecostalismo, iniciou sua carreira como pastor da Igreja do Evangelho Quadrangular, construiu um trabalho sólido de evangelização em sua cidade natal, e tornou-se responsável por uma congregação numerosa e estável de fieis. Após provar, de forma bem-sucedida, sua capacidade pastoral de arregimentação e ma-

${ }^{1}$ A Igreja do Evangelho Quadrangular faz parte da chamada segunda onda pentecostal dos anos 50 . 
nutenção de adeptos, ele foi convidado para assumir uma igreja voltada para o público de classe média na cidade de Uberlândia-MG. Contudo, o pastor que desocuparia a vaga continuou na administração do templo, e Marcos permaneceu na cidade sem conseguir realizar o ofício de pregação, o que o obrigou a se virar em trabalhos não qualificados, informais e precários, na construção civil. Um dia, ouviu falar na abertura de uma ocupação de luta pela moradia urbana na periferia da cidade e decidiu abrir uma igreja na mesma. A trajetória de Marcos como pastor tem uma espécie de fratura: de pastor assalariado responsável por uma congregação de adeptos, vinculado a uma denominação pentecostal tradicional, ele se torna pastor autônomo, trabalhador por conta própria, engajado na ministração de cerimônias esporádicas e no atendimento dos dramas dos moradores da ocupação, em uma igreja que não tem nome. Na ocupação, sua "igreja" é "condenada" a funcionar sob uma existência clandestina, embora a ausência de uma nomeação pode também estar relacionada ao fato de que a Igreja do Evangelho Quadrangular não mais o reconheça como um pastor vinculado à sua estrutura eclesiástica. Qual posição então ocupa então Marcos no campo pentecostal?

Em sua crítica à caracterização sociológica do profeta de Max Weber (2000), Pierre Bourdieu (1999) argumenta que o êxito do profeta seria incompreensível se a análise fiন̃ casse restrita à invocação de uma capacidade is milagrosa, ou seja, "uma criação ex-nihilo de ㅇ capital religioso" (Bourdieu, 1999, p. 73), como \& se o carisma pudesse brotar do nada. O "hoホi mem extraordinário”, de que falava Weber, é

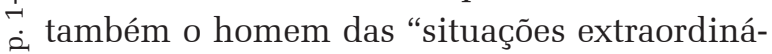
கீ rias", aquele capaz de "traduzir", em palavras $\dot{\Delta}$ virulentas e desconcertantes, as "virtualidades heréticas" dos leigos, aquele que nomeia o que ainda não havia sido nomeado, em contextos de crise, em que se observa a "dissolução, o enfraquecimento ou a obsolescência" dos "sistemas simbólicos que forneciam os princípios da visão do mundo e da orientação da vida"
(Bourdieu, 1999, p. 73). Além disso, para que se supere o conceito de carisma como uma propriedade inexplicável de indivíduos singulares, é preciso ainda investigar as "características sociologicamente pertinentes" (ibidem, p.75) que fazem algumas biografias singulares se tornarem predispostas a assumir o lugar dos profetas, e mais do que isso, delimitar quais são as frações de classe/grupos sociais de onde eles historicamente provém.

\begin{abstract}
Em particular, seria preciso analisar os fatores que predispõem as categorias e os grupos estruturalmente ambíguos, mancos ou bastardos (palavras escolhidas por sua virtude evocatória), ocupando lugares de grande tensão estrutural, posições inconsistentes e pontos de Arquimedes (por exemplo, os forjadores em inúmeras sociedades primitivas, a intelligentsiaproletaróide nos movimentos milenaristas ou, em nível psicossociológico, os indivíduos com status demasiado oscilante) a cumprirem a função que lhes cabe tanto no estado normal de funcionamento das sociedades (manipulação das forças perigosas e incontroláveis) como nas situações de crise (formulação do informulado) (Bourdieu, 1999, p. 74-75).
\end{abstract}

Assim, Bourdieu (1999) concorda com a afirmação weberiana de que os profetas nunca provieram da camada sacerdotal burocraticamente organizada, detentora do capital religioso da interpretação dos dogmas; ao contrário, eles são oriundos das camadas dos leigos, ao mesmo tempo que "é específico nos profetas que assumam sua missão não por serem encarregados pelos homens, mas por usurpação" (Weber, 2000, p. 306). Mas avança em relação à interpretação weberiana ao demonstrar que os profetas surgem de "grupos estruturalmente ambíguos, mancos ou bastardos" (Bourdieu, 1999, p. 75), com posições "inconsistentes", "vacilantes", "incertas". Embora tenha construído um esquema conceitual para caracterizar a origem social dos profetas, que revolucionam a história ao instituir uma nova religião ou reformar uma antiga, sua análise oferece pistas teóricas que contribuem para a investigação da dinâmica das lutas simbólicas no interior do campo do pentecostalismo. 
O movimento pentecostal brasileiro teve como "camada portadora" (Weber, 2000) as classes dominadas. Não as classes dominadas de forma geral, mas uma fração de classe específica: uma "massa enorme de gente nas franjas da sociedade, sem um lugar específico no sistema de produção" (Souza, 2010, p. 275). A Apostholic Faith Mission, fundada por Willian Joseph Seymour na Azuza Street, em Los Angeles, mito de origem do pentecostalismo, era formada por "negros, imigrantes e um número significativo de mulheres" (Souza, 2010, p. 273). Em sua expansão pelo mundo ao longo do século XX e no início do século XXI, o pentecostalismo manteve "sua 'vocação' inicial para atender as demandas das classes subintegradas da sociedade capitalista” (Souza, 2010, p. 274), tornando-se "a força mais dinâmica e expansiva do cristianismo no mundo, crescendo nas regiões em que as contradições do capitalismo se tornaram mais radicais, como é o caso da crônica desigualdade social da América Latina" (Souza, 2010, p. 274). Assim, o movimento pentecostal nasce nas margens do processo de implantação de uma sociedade urbano-industrial nos trópicos. A possibilidade de dispor do sagrado por meio da intervenção extramundana do Espírito Santo permitia aos sujeitos marginais subverterem o jogo social do campo religioso. Não apenas os membros da camada sacerdotal do protestantismo histórico, dotada do capital simbólico da formação teológica, poderia acessar a verdade da revelação - a experiência corporal do transe místico poderia ser tão ou mais poderosa do que o conhecimento acadêmico das escrituras. Assim, o movimento pentecostal se constituía como o "bastardo" do protestantismo ascético. Mas no interior do próprio pentecostalismo, que ocupa, do ponto de vista relacional, uma posição "manca" perante o puritanismo metódico, as posições de "autorizados" e "bastardos" não estão previamente - e irremediavelmente - estabelecidas, mas são sempre usadas em performances de acusação do outro, em dinâmicas sempre relacionais; negociadas entre os sujei- tos que se engalfinham nas lutas simbólicas do campo. Assim, na clivagem entre legítimos e ilegítimos, na tensão entre ortodoxia e heterodoxia, as posições nunca são definidas de uma vez por todas. Marcos, por exemplo, condensa em sua trajetória a instabilidade do campo pentecostal: de pastor formalizado, em um contrato estável com uma denominação tradicional, para pregador autogestor, que se arrisca em um empreendimento privado de abertura de sua própria (não-nomeada) denominação. Em sua narrativa, ele parece se ressentir da perda do seu antigo status na carreira de pregação no mesmo passo que reconstrói sua história a partir do testemunho de superação das adversidades e engajamento em sua nova vocação missionária. Ainda que Marcos possa ocupar a situação de "ilegítimo" para sua denominação de origem; dessa mesma posição, ele ensaiou outros lugares possíveis, como a criação de uma "igreja" em um terreno de luta pela moradia. Ao contrário da rigidez eclesiástica e hierárquica do catolicismo, o pentecostalismo se forma como um campo aberto e plástico, onde novos empreendimentos sacrais são sempre possíveis, ainda que seja na inauguração de um espaço de culto em uma ocupação - ela também, de forma homóloga, uma formação urbana "bastarda", nas fronteiras entre o legal e o ilegal, o lícito e o ilícito.

A história de Marcos me fez revisitar os pregadores-itinerantes que eu havia pesquisado no doutorado, de 2007 a 2011. Como vimos, os pregadores-itinerantes ocupavam as posições mais "mancas" no mercado de pregações, cujo único trunfo era o testemunho de transformação de vida, uma espécie de mercadoria simbólica efêmera, que corre o risco de se esgotar tão logo é consumida, como um palito de fósforo que só se pode riscar uma única vez. Em um dos testemunhos que adquiri na época, assisti a performance de Wellington Bispo, um jovem negro, em torno dos seus vinte anos, vestido com um terno cor de laranja, em uma vigília evangélica em uma escola periférica de São Paulo. O ex-mendigo que se tornara prega- 
dor ora contava sua história de morador de rua na praça da Sé, ora provocava transes extáticos no público, que rodava e caía sob a invocação "Receba!", que Bispo gritava de forma gutural, rouca e prolongada, com a boca grudada ao microfone, em referência à entrega à unção do Espírito Santo. Em meio à sua pregação, ele dizia: "Eu vou entregar tudo, porque eu tenho uma mensagem de Deus. 'Porque a teologia diz que o pastor, pela homilética... [emulando um pastor arrogante]. Tem que pregar pregado, não pode sair! 'Porque pela teologia...”. Eu conheço um pregador de longe, ele prega com o diafragma”. De sua posição "bastarda" no campo religioso, o mendigo que virou pregador escancara as tripas do jogo social do mercado de pregações, como se pregasse por usurpação, com a autoridade dos ilegítimos, que não tem contas para prestar nem vínculos eclesiais para honrar, pois opera na informalidade do trabalho religioso. Como virador do pentecostalismo, ele despreza o pastor investido de sua autoridade teológica e afirma a palavra virulenta, das entranhas impuras do seu corpo infame de ex-mendigo, ex-aidético, ex-morto, daquele que pode dizer tudo porque não tem nada a perder. Nas duas narrativas de pregação, a de Marcos e a de Bispo, observa-se uma espécie de reflexão simbólica da própria condição social, em que ambos se pensam a partir das situações vacilantes que ocupam no universo pentecostal, suas trajetórias mutiladas de dramas sociais, নี sua inscrição na trajetória de pregação, como N pastor de ocupação ou missionário desterritoS rializado. Mas, ao mesmo tempo, observa-se \% em ambos uma recusa da humilhação social, ホָ dramatizada seja no ressentimento pelo declí$\therefore$ nio da própria profissão pastoral, seja na braमे vata contra os pastores formados em teologia.

A "habitação" (Das, 2020) da humilhacão social é um dos componentes estruturantes do pentecostalismo, que pode ser identifiI cado desde a sua genealogia afro-americana. Os "pontos-cegos" do nosso esforço heurístico durante as três décadas de Nova República, aquilo que não fomos capazes de ver, come- çam, de alguma forma, a se cruzar. O acionamento teológico da guerra fazia sentido a partir de sujeitos que falavam de uma determinada experiência social, que começa a se constituir nas franjas da implantação da primeira onda de neoliberalização à brasileira. Ao escorregar entre o "mundo do crime" e o "mundo pentecostal", ele oferecia uma grade de inteligibilidade pelo qual os sujeitos podiam recobrir de significado trajetórias de outro modo fraturadas. Essa teodiceia da guerra só pode operar como uma doutrina racionalmente coerente de explicação para o sofrimento percebido como injustamente merecido (Weber, 1982; 2000), para sujeitos que viviam, agiam e falavam de um determinado lugar social, na estrutura das frações de classe da sociedade brasileira. E esse lugar falava da humilhação.

\section{O DISPOSITIVO DA HUMILHAÇÃO}

Em seu artigo O problema da formação do "cinturão pentecostal" em uma metrópole da América do Sul, Clara Mafra (2011) elabora uma hipótese importante ao tomar como ponto de partida uma cena microssociológica aparentemente fortuita. Ela conta que estava em seu apartamento preparando o referido artigo, quando Paula, sua amiga crente, moradora da Magé e diarista em uma casa classe média no bairro de Santo Teresa, a telefonou.

Depois de um preâmbulo, Paula, com a voz entristecida, contou: "hoje a minha patroa me serviu feijão sem carne”. Não entendi nada e pedi mais explicações: “como assim, "feijão sem carne?". Paula explicou. O costume naquela casa é que, enquanto Paula faz a faxina, a patroa vai para a cozinha e prepara o almoço. Feito o almoço, primeiro a família almoça, em seguida, a patroa deixa o prato da empregada servido sobre a mesa. Naquela terça-feira, o prato que estava na mesa trazia feijão e arroz. Paula comeu e, quando foi pegar água na geladeira, viu uma tigela com as carnes do feijão. A patroa tirou as carnes do feijão para servir o prato da faxineira. Sem muita demora, Paula deduziu o efeito simbólico implícito no gesto: "ela [a patroa] quer que eu me sinta 
inferior. Mas eu não sou inferior. Hoje à noite, na minha casa, vou me ajoelhar e clamar a Deus. Vou pedir por mim, para que eu suporte essa tribulação, e pela patroa, porque ela não sabe o que faz" (Mafra, 2011, p. 138-139).

Receber da patroa o feijão sem carne, sobre a mesa, é percebido por Paula como humilhação. Ainda que as classes trabalhadoras brasileiras conheçam, vivenciem e recusem há décadas as formas de humilhação do mundo do trabalho, na relação entre patrões e empregados, para Mafra (2011), há um componente novo na formulação de Paula. Na argumentação de Mafra, em contextos marcados pela retórica da legitimação da desigualdade entre os homens ritualizada pelo catolicismo tradicional, "parte-se do princípio de que os homens são desiguais e que, portanto, alguns nascem para patrão, outros para empregado; alguns nascem para mandar, outros para obedecer" (Mafra, 2011, p. 139). Para a antropóloga, se Paula compartilhasse dessa grade de leitura, "ela sequer compreenderia a situação como de humilhação” (Ibidem, p. 139). Ainda que Mafra possa não ter reconhecido, suficientemente, as formas de percepção da injustiça e as modalidades cotidianas de resistência que os trabalhadores brasileiros historicamente acionaram, ${ }^{2}$ a despeito da impregnação corrosiva da "violência simbólica", internalizada por "categorias impensadas" que compõe uma héxis corporal da opressão de classe (Bourdieu, 1999), o argumento da autora traz uma chave de leitura que merece atenção. Paula sente a injúria do feijão desprovido de carne, mas mais do que isso, ela formula uma linguagem para descrever seu sentimento de ultraje: "ela quer que eu me sinta inferior. Mas eu não sou inferior”. Essa formulação é possível porque houve um cruzamento entre dois processos distintos: o pertencimento ao pentecostalismo e a formação de espaços segmentados nas re-

${ }^{2}$ Agradeço a minha querida amiga e socióloga do trabalho Ludmila Costhek Abílio pela discussão teórica a respeito desse tema e por ter me chamado a atenção sobre o reconhecimento das modalidades de resistência que as classes trabalhadoras mobilizaram ao longo da história brasileira. giões periféricas. Segundo a autora, a partir da década de 1980 no Brasil, observa-se a configuração de um "cinturão pentecostal” no entorno das áreas centrais das grandes cidades, composto por uma massa de pobres e miseráveis, adeptos do pentecostalismo, habitantes das favelas, bairros e subúrbios periféricos. Nessa nova composição das metrópoles, com espaços segmentados e exclusivos, os sujeitos moradores das margens, encapsulados em seus enclaves, passaram a se afastar do "padrão hierárquico relacional tradicional, paternalista e fideísta" (Mafra, 2011, p. 140), que regulava as relações entre classes abastadas e trabalhadoras, superiores e subordinados. O afastamento desse modelo católico de naturalização da exploração social criou condições para que os sujeitos periféricos fabricassem, nas margens, seus próprios mecanismos de sociabilidade, focados em relações intraclasse. O pentecostalismo ofereceu então, de forma plástica, uma nova gramática social e simbólica, capaz de traduzir como os sujeitos pensam seus lugares no mundo social, suas posições de classe, raça e gênero - o que pode incluir a recusa das formas tradicionais de humilhação social em uma sociedade radicalmente estratificada.

A gestação de um “cinturão pentecostal", a partir da década de 1980, é a radicalização de um processo que tem sua genealogia na própria formação do pentecostalismo na América Latina, nas margens do processo de implantação de uma sociedade urbano-industrial nos trópicos. A formação de "enclaves pentecostais" nas periferias fomentava a ruptura com a subserviência servil em relação aos membros das camadas médias. O afastamento das relações de prestação de serviços/contraprestação de favores, próprias das interações com os "patrões”, implicava também uma rejeição sutil aos signos de status de classe, como a posse de diplomas universitários, o exercício de profissões qualificadas e a aquisição de conhecimentos especializados. Esse processo histórico pode ter contribuído para a fabricação de um dispositivo que nem sempre é enfatizado nas 
interpretações sobre o pentecostalismo: seu caráter antiautoritário. Desde sua gênese, o movimento é marcado por uma contestação da autoridade, em suas múltiplas encarnações, desde a autoridade da teologia, passando pela autoridade do conhecimento científico e da mídia mainstreem. No contexto da pandemia, hoje pode-se observar isso nas posições políticas de parte das igrejas pentecostais, que se colocaram contra as medidas sanitárias de isolamento social para controle do contágio do coronavírus. Em alguns casos, elaborou-se uma narrativa que vê na gestão política da doença técnicas de controle dos movimentos dos corpos dos indivíduos, interpretados como formas insidiosas de uma ameaça totalitária contra os direitos civis e sinas inequívocos de uma antecipação do fim do mundo, em uma releitura pentecostal do Apocalipse. ${ }^{3}$ Ao final da argumentação deste artigo, discutiremos como o dispositivo anti-autoridade do pentecostalismo guarda "conexões de sentido" com a sublevação contra a autoridade própria do bolsonarismo. Antes, debateremos como no contexto do processo de neoliberalização à brasileira, estabelece-se uma relação entre a recusa da humilhação e o empreendedorismo periférico.

\section{EMPREENDEDORISMO PERIFÉRICO}

Ao partir da noção originalmente forసิ mulada por Michel Foucault (2008a; 2008b), is Giorgio Agamben (2009) propõe o conceito de N dispositivo como "qualquer coisa que tenha de ¿े algum modo a capacidade de capturar, orienホi tar, determinar, interceptar, modelar, controlar $\overrightarrow{2}$ e assegurar os gestos, as condutas, as opiniões में e os discursos dos seres viventes" (Agamben, 2009, p. 40) ${ }^{4}$. Para ele, uma "geral e maciça

${ }^{3}$ Sobre isso, ver artigo (preprint) de Mariana Côrtes e Jacqueline Moraes Teixeira (2021). Disponível em: https://er. ceres.rub.de/index.php/ER/article/view/9262/8800. Acesso em 12.10.2021.

gamben, não apenas "as prisões, os manicômios, o Panóptico, as escolas, a confissão, as fábricas, as disciplinas, as medidas jurídicas etc.” podem ser considerados dispositivos, "mas também a caneta, a escritura, a literatura, divisão do existente" poderia ser efetuada em dois grandes grupos: os seres viventes e os dispositivos, em que os primeiros "são incessantemente capturados" (ibidem, p. 40). Além dos dois, e entre os dois, como terceiro elemento, existe os "sujeitos". Na relação - no corpo a corpo - entre os dispositivos e os viventes, produz-se os sujeitos, que são resultado de uma fabricação incessante, que não tem um um lócus definitivo nem um telos a ser alcançado, de processos permanentes de subjetivação. Nesse sentido, os viventes (as substâncias) não necessariamente coincidem com os sujeitos, pois um mesmo "vivente" pode ser atravessado, entrecortado e capturado por diversos processos de subjetivação e assumir diferentes figurações no cotidiano, como o bandido, o policial militar, o crente, o filho, o pai, o usuário das redes sociais, o apoiador do Bolsonaro, entre infinitas possibilidades. Assim, o pentecostalismo pode ser pensado não apenas como uma "doutrina teológica", uma "congregação de fiéis", uma "empresa de salvação" ou um "serviço mágico". É uma tecnologia social de condução da conduta dos sujeitos periféricos, que opera por múltiplos dispositivos, em que os indivíduos são ao mesmo sujeitos e objetos dessa condução. Um desses dispositivos é o dispositivo do sofrimento (Machado, 2014), que funciona, no pentecostalismo, por meio do diagrama da humilhação. Por meio da estrutura do testemunho, os sujeitos estabelecem uma relação de si para consigo em torno da experiência da dor, uma narrativa de vida que descreve os dramas vividos, de forma que o conteúdo patológico (no sentido original do termo grego pathos) deve ser encenado como excesso e transbordamento. A máquina do testemunho produz a necessidade de se falar incessantemente sobre o passado pregresso e o momento inaugural da conversão, que deve ser atualizado indefinidamente, em uma espécie

a filosofia, a agricultura, o cigarro, a navegação, os computadores, os telefones celulares e - por que não - a própria linguagem, que talvez é o mais antigo dos dispositivos, em que há milhares e milhares de anos um primata - provavelmente sem se dar conta das consequências que se seguiram - teve a inconsciência de se deixar capturar" (2009, p. 41). 
de motum perpetum. Uma narrativa, portanto, que precisa ser infinitamente repetida, uma máquina cuja operação não pode ser cessada, cujo modus operandi é falar de forma ininterrupta. Os sujeitos pentecostais se criam - e são criados - nesse mecanismo de subjetivação em que a "verdade" do sofrimento, de forma nua, crua, às vezes escatológica, por vezes grotesca, deve ser sempre encenada. Nas congregações pentecostais, a máquina do testemunho se constituiu como o espaço narrativo que oferecia visibilidade para a enunciação dos dramas recorrentes e organizava as experiências de vida fraturadas dos sujeitos habitantes das margens. Por meio do testemunho, os sujeitos periféricos também anunciavam - e reconheciam - seus lugares de humilhação social.

De forma inusitada, o dispositivo da humilhação começou a ser conectado com outro dispositivo: o do empreendedorismo periférico. A partir dos anos 1990, as ciências sociais brasileiras se voltaram para o fenômeno da Teologia da Prosperidade, disseminada nas denominações neopentecostais, como uma premissa teológica que pressupunha que os fiéis deveriam adquirir "bens mundanos" nessa vida, como saúde, amor, emprego, dinheiro, e não adiar a satisfação para a vida após a morte (Pierucci \& Prandi, 1996; Campos, 1997; Mariano, 1999). A conquista da prosperidade pressupunha, contudo, uma espécie de contrato entre o fiel e Deus, na qual quanto mais ousado fosse o fiel na oferta em dinheiro (ou em bens materiais) para Deus, maiores eram as chances de ser recompensado com bênçãos multiplicadas. A Teologia da Prosperidade era uma barganha mágica que atendia demandas desesperadas e agudas de uma população flutuante e miserável, mas não continha, em si mesma, um fundamento motivacional para a construção de uma disposição econômica duradoura e estável. Contudo, a partir de 2010, principalmente no âmbito da Igreja Universal do Reino de Deus, que condensa uma síntese radical de certas tendências teológicas, organizacionais e eclesiásticas do chamado neopentecostalismo, observa-se uma inflexão na Teologia da Prosperidade, pois essa deixa de ser simplesmente uma negociação mágica para se tornar uma espécie de racionalização econômica da conduta de vida. Nesta, tem-se o exercício de uma "fé racional" ou uma "fé inteligente", na qual o adepto deve estabelecer uma nova relação de si para consigo, que implica racionalizar a rotina, cumprir desafios, estabelecer metas, trabalhar para a criação de si próprio como um capital humano que deve ser sistemática e infinitamente valorizável (Gutierrez, 2017; Abreu, 2017). Em sua tese, Jacqueline Moraes Teixeira (2018) demonstra que a "fé racional" implica uma ideia de sacrifício, de controle dos afetos e disciplina do corpo, o que pode indicar uma correspondência de sentido com a dimensão sacrificial do neoliberalismo contemporâneo (Brown, 2018), na qual o capital humano deve operar como uma "máquina-fluxo", um motor que expurga o próprio corpo (e o passado), em um calvário imanente (Viana, 2014), para que novas rendas, matérias ou psíquicas, sejam acionadas (Côrtes, 2020a). Nessa nova modulação da subjetividade, a Igreja Universal começou a formular um fundamento teológico para o empreendedorismo, que incitava os fiéis a estabelecer uma nova relação com eles próprios em torno da fabricação de si como empreendedor. Ser empreendedor passou a significar a possibilidade de abraçar o risco de abrir o próprio negócio e recusar a identidade do trabalhador como empregado, que passa a ser visto como alguém se encontra subjugado a um patrão, em uma relação de servidão. Por meio de uma surpreendente inversão, a carteira assinada, meta de um sonho socialdemocrata no qual a aquisição de direitos sociais se daria pelo ingresso na sociedade salarial, torna-se signo de submissão. Em um programa televisivo da Igreja Universal no canal aberto Record, no ano de 2018, o pastor que conduzia a preleção citou uma passagem bública de Números 29:1: "Convocação no sétimo mês, no primeiro dia do mês, nenhum trabalho servil fareis; será para vós dia de sonido de trombetas". A passagem 
era interpretada como uma revelação profética de que no próximo 01 de julho seria o dia em que os sujeitos submetidos a trabalhos servis seriam emancipados. Por uma reviravolta inaudita, o emprego formal é recoberto pelo signo da humilhação.

Nesse contexto, a Igreja Universal não tinha mais como público alvo apenas a chamada "ralé estrutural" (Souza, 2012), mas introduzia um novo regime de condução das condutas para um novo grupo possível de adeptos: a fração de classe que havia ascendido durante os governos petistas para estratos médios de renda, que se tornaram conhecidos no polêmico e divergente debate acadêmico de então como "nova classe média”, "classe C" na terminologia de pesquisas de mercado, ou ainda "batalhadores”, no conceito proposto por Souza (2012). Como aparece na argumentação da apresentação do presente dossiê, a partir de 2007, um mercado novo de baixa renda, composto por uma classe trabalhadora pouco ou nada qualificada, se configura como "objeto de uma série de novos dispositivos de poder e saber por parte do Estado, de governos locais, de empresas, de bancos e de financeiras" (Almeida, Andrade \& Côrtes, 2021). Tratava-se da segunda onda de neoliberalização voltada a gestão desses novos "trabalhadores urbanos", "de modo a moldar a sua conduta de consumo, a construir um novo sujeito financeiro, a induzi-lo à disciplina do trabalho pelo novo espírito do capitalismo, a స̃ converter a viração em empreendedorismo ข Æ̛ं dos judeus da escravidão dos faraós egípcios $\dot{\Delta}$ é convocada para oferecer uma justificação teológica para a rejeição do emprego formal e o engajamento na empreitada do empreendedoIismo periférico. ${ }^{5} \mathrm{~A}$ duradoura tragédia da "vi-

${ }^{5}$ Em uma das incursões ao trabalho de campo na ocupação Jardim Vitória, na cidade de Uberlândia-MG, Luciano Senna e Cláudia Swatowiski, coordenadores, junto comigo, do Travessias - Núcleo de Pesquisas Urbanas, presenciaram ração" brasileira (Telles, 2010; Abílio, 2020); a impossibilidade de acesso aos direitos sociais; a precarização do trabalho nas formas desprotegidas da informalidade, se revestem de um discurso religioso criativo, e audaciosamente eficaz, pois aciona o diagrama da humilhação.

Na experiência da violência no cotidiano, os trabalhadores urbanos não têm como não a reconhecer, impregnada que está na viscosidade da pele de quem coleciona ultrajes do mundo do trabalho, como a expropriação da carne do feijão.

Assim, entre neoliberalismo e neopentecostalismo, a relação não é de imposição de cima para baixo de uma racionalidade que vem de fora e ocupa um espaço vazio que deverá obrigatoriamente aceitar os ventos do admirável mundo novo. O neopentecostalismo não reelabora o neoliberalismo de forma passiva em uma adesão "subalterna" à premissa do homo oeconomicus. Ao contrário, produz um agenciamento perspicaz no qual ser empreendedor significa livrar-se da submissão contida na posição de empregado subalterno à autoridade arbitrária do patrão. Nos pontos de fricção entre Estado e margens, entre governo neoliberal e governo neopentecostal, fabrica-se uma co-produção de um empreendedorismo periférico. De um lado, as políticas sociais adotadas durante os governos petistas, como os programas de transferência de renda, de acesso à casa própria, de facilitação ao crédito popular, a criação da figura do MEI (microempreendedor individual); e posteriormente, a partir da gestão de Michel Temer, a reestruturação do mercado de trabalho com a Reforma Trabalhista, a adoção de formas de gerenciamento do trabalho por meio dos aplicativos uma plenária do movimento de luta pela moradia urbana em que se encaminhava para a votação a discussão sobre se os moradores deveriam ou não resistir à reintegração de posse que seria realizada pela polícia, o que implicaria a destruição de barracos e uso da violência. A maioria tendia a não resistir em razão da presença de velhos, mulheres e crianças. Um senhor, contudo, solicitou a palavra e apresentou um argumento novo: do mesmo modo que os judeus haviam lutado contra imperadores egípcios, era necessário que os moradores resistissem à polícia. Seu voto foi vencido. Como se vê, em uma microcena, pontual e isolada, o diagrama da humilhação pode-se deslocar, de forma conjuntural, para a agenda de luta pelos direitos sociais. 
(Abílio, 2020), contribuíram para fomentar uma "subjetividade contábil” (Dardot \& Laval, 2016) entre os trabalhadores urbanos. De outro lado, a Igreja Universal, um caso paradigmático no neopentecostalismo, e seu agenciamento dos meios midiáticos e das redes sociais, criou um mecanismo sofisticado de subjetivação em que empreender é livrar-se da servidão a um senhor, lugar historicamente destinado aos dominados. Desse modo, a Igreja Universal foi capaz de capturar um dispositivo da humilhação - que tem uma longa tradição no interior do pentecostalismo - e fazê-lo funcionar como fundamento ético-motivacional do empreendedorismo, seja na forma do empreendedorismo do "batalhador", seja na forma do empreendedorismo da "ralé" (Souza, 2012). Cria, assim, um "híbrido impuro", resultado de cruzamentos estranhos, entre a injunção neoliberal do "empresário de si mesmo" e a insubordinação dos "bastardos" que não querem mais ser humilhados. Aqui, a sublevação contra a humilhação se encenava também no mundo de trabalho: em defesa do mercado, contra os "senhores", todos deveriam se lançar na guerra da concorrência.

Nesse momento da argumentação do artigo, talvez estejamos em condições de enfrentar um dos fios heurísticos do engastalhado enredo da virada autoritária do neoliberalismo brasileiro, que permite atrelar o pentecostalismo ao bolsonarismo. Ambos, cada um ao seu modo, constituem-se como uma "revolta dos bastardos", ambos pretendem uma reparação - por vezes violenta, algumas vezes vingativa - contra a humilhação; ambos acreditam estarem ao lado de uma verdade aletúrgica e inspiracional, que fala a linguagem do "coração", não da doxa acadêmica e pretensiosa dos especialistas (Bourdieu, 2001).

\section{DAS MARGENS AO ESTADO}

$\mathrm{Na}$ orientação teórico-metodológica do presente artigo, proponho pensar o bolsonarismo como um fenômeno multicausal que comporta uma constelação de conexões de sentido possíveis a depender de qual variável histórico-social será eleita pelo(a) pesquisador(a) como significativa para compreensão do fenômeno, e mesmo que seja improvável que um dos nexos causais escolhidos seja capaz de esgotar o redemoinho sombrio que nos assalta, cada esforço heurístico contribui para encaixar uma peça no confuso quebra-cabeça. Isso significa também dizer que o fenômeno do bolsonarismo pode ser interpretado de forma diferente conforme a classe social, a fração de classe social, o grupo profissional, o segmento religioso. Em suma, se a proposta teórico-metodológica propõe investigá-lo sob o prisma das margens, segundo a ideia de um bolsonarismo de base popular (Feltran, 2020; 2021; Pinheiro-Machado \& Scalco, 2018; 2020); como uma conspiração das elites contra os pobres; como um ethos próprio da classe média, ou, ainda, de uma fração específica da classe média. De qualquer forma, o mais provável é que o "bolsonarismo" seja uma composição hibridizada de todas essas extrações de classe social, compondo o que Rodrigo Nunes (2021) denominou de um "fenômeno intraclasses". Contudo, cada opção teórica parece enfatizar um ângulo específico sobre o jogo das classes sociais ao compor sua hipótese para a decifração do nosso imbróglio autoritário.

Para Nunes, por exemplo, uma camada social pode ser considerada a portadora por excelência do bolsonarismo: "É no nicho da baixa alta classe média que o bolsonarismo mais convicto se criou e se mantém" (Nunes, 2021, p.1). Ao tomar de empréstimo uma expressão de George Orwell, a "baixa alta classe média" designaria um "estrato de pessoas" que se situam na classe média ou média alta, mas encontram-se numa posição vacilante dentro dessa mesma classe, pois embora sua renda os permita ocupar essa camada, "faltam-lhe a riqueza acumulada em ativos e o capital cultural e social de pessoas com padrões de vida semelhantes" (Nunes, 2021, p.1). Para Nunes, “a condição de 'lúmpen-elite' as torna presa 
fácil de um ressentimento dirigido tanto para cima quanto para baixo". Ressentem-se dos de cima porque esses dominam códigos, cultivam conexões e detém riquezas que não são acessíveis a eles. Ressentem-se dos de baixo, porque parte deles "usurparam" os marcadores de distinção social que os garantiam status exclusivo. A sensação de irritação contra os que supostamente estavam trapaceando no jogo da concorrência (funcionários públicos, políticos corruptos, professores universitários, intelectuais e artistas progressistas, quilombolas, cotistas, maconheiros, feministas, grupos LGBTQIA+, uma elite globalista, entre outros, todos caracterizados pela categoria englobante de "vagabundo") receberam uma narrativa consistente nos movimentos civis das novas direitas que se organizaram no Brasil a partir dos protestos de Junho de 2013, e também na fala de Jair Bolsonaro, reverberada de forma exponencial por meio do engajamento voluntário e o gerenciamento algorítmico de suas milícias digitais, humanas ou não. Segundo Nunes (2021), do interior desse nicho social, surgiram não apenas os seus seguidores mais fanatizados, mas organizadores do movimento, intelectuais orgânicos, influenciadores digitais ou políticos de carreira, que transformaram o próprio bolsonarismo em um empreendimento em si mesmo, um novo modelo de negócios.

Na medida em que a instabilidade política e econômica revelou a existência desse filão, centenas de empresários falidos, roqueiros decadentes, atores fracassados, jornalistas de reputação duvidosa, subcelebridades "ativistas", traders batalhadores, coaches medíocres, policiais e militares buscando complementar a renda - toda a fauna pitoresca dos agitadores "conservadores", "patriotas", "liberais” e "anarcocapitalistas" - encontraram nele a oportunidade de uma nova carreira (Nunes, 2021, p. 1).

Embora membros da "baixa alta classe média” (Nunes, 2021) possam racionalizar, radicalizar e propagar conteúdos significativos do bolsonarismo, além de oferecer sujeitos que ocupariam posições nos poderes institucionais, nos movimentos civis e nas plataformas digitais, esses atores, bem como agentes do mundo industrial e financeiro (a elite propriamente dita), como mostra de forma convincente Gabriel Feltran $(2020 ; 2021)$, entraram no jogo depois, a partir de 2013, quando grupos ideológicos de extrema direita passaram a se articular em escala internacional. Esses grupos ideológicos "seguiriam irrelevantes em escala nacional” (Feltran, 2020, p. 1) se o bolsonarismo não contasse com um movimento de massas que o sustenta nas periferias, e se essas massas "não tivesse as bases econômicas que têm, em primeiro lugar, nos mercados de proteção e, em seguida, nos mercados religiosos" (Ibidem, p. 1). O bolsonarismo não é um movimento originalmente de classe média (ou de uma fração da mesma); ao contrário, ele é o resultado de movimentos que operam insidiosamente nas periferias, há pelo menos trinta anos. Portanto, o que se observa, na última década, é "uma força centrípeta - das margens ao centro - arrastar as garantias institucionais e rebaixar a política ao plano da violência bruta” (Feltran, 2021, p. 1). Para o pesquisador, a nossa virada autoritária deve ser investigada sob a perspectiva das margens e o "trabalho de base" que policiais, militares e pastores evangélicos realizaram nas periferias, cuja construção na rotina de vida dos sujeitos periféricos pode sobreviver, e até mesmo se virar muito bem, sem o presidente-capitão que hoje os representa. O movimento "de base" - que se seguia à sombra dos olhos da classe média - aos poucos foi alcançando posições institucionais em todos os poderes (Legislativo, Executivo e Judiciário), em todos os âmbitos (federal, estadual e municipal), ao ocupar funções que vão de conselhos municipais a ministérios. Em seu texto mais recente, Feltran (2021) foca em dois regimes normativos atuantes nas periferias: o das facções criminais e das forças policiais e milicianas. As facções criminais, hoje conectadas a redes internacionais de mercados ilegais, se fortaleceram nas margens urbanas ao incorporarem "códigos de honra" e "sensos de justiça” operantes há muito nas "comunida- 
des", cujo fundamento é "velhoestamentista": não se deve dar falso testemunho (caguetar); cobiçar a mulher do próximo (talaricar); roubar (na quebrada); ou matar (sem permissão da facção). Como reação à presença das facções criminais nas periferias, as forças policiais se organizaram não apenas para fomentarem um plano genocida de eliminação dos indesejáveis (os jovens pobres e pretos nos baixos escalões das redes criminais), mas para formarem "mercados de proteção", que hoje se estendem em modelos de negócios que reinvestem o capital acumulado em uma diversidade de operações ilegais, da proteção veicular a grilagem de terras. Ao contrário das facções criminais, que operam apenas nos mercados ilegais, parte das forças policias (e milicianas) tem projetos claros de ocupação do Estado. Além do expediente de pilhagem de "traficantes, desmanches, lojistas, moradores" (Feltran, 2021, p. 1), contam com os fundos públicos como sustentação de sua base econômica, generosamente ampliados no governo Bolsonaro. ${ }^{6}$

Ao perscrutar os regimes normativos que tecem a vida cotidiana nas margens, Feltran $(2020 ; 2021)$ investigou as fronteiras de tensão que costuram as relações entre moradores, trabalhadores informais, entregadores de comida, serventes de pedreiro, terceirizados, diaristas, catadores de lixo, irmãos de fações, crentes, obreiros, pastores, policiais, milicianos, agentes do Estado e do terceiro setor. Em paralelo, o presente texto tentou retraçar os percursos do pentecostalismo nas últimas décadas, e como é possível pensa-lo também como uma "força centrípeta", que empurra as margens para o centro do poder político. De um lado, o Estado passou a operar por meio de um governo seletivo que recorta a popula-

${ }^{6}$ Segundo Feltran, "as despesas executadas no Orçamento da União em 2020 nas áreas da Defesa (R\$ 73 bilhões), da Segurança (11 bilhões) e da Polícia Federal (7 bilhões) já comporiam base material suficiente para sustentar um projeto de poder nacional. O centro deste projeto hoje liderado por Bolsonaro está, entretanto, nas Secretarias de Segurança e de Administração Penitenciária dos 27 estados.

Daí saem os fundos que abastecem as Polícias Militares e Civis, algo em torno de 170 bilhões de reais por ano" (2021, p. 1). ção segundo critérios de precariedade e risco. Do Estado às margens, os grupos segmentados, recortados segundo esses critérios, produziram seus próprios dispositivos e modos de subjetivação. Contudo, o movimento contrário também se produziu: das margens ao Estado. Como mostra Foucault (2008a; 2008b), o Estado não é um grande demiurgo sobre o qual os analistas devem desvendar seu segredo, uma metafísica da soberania sempre igual a si mesma, cujo telos é realizar a tarefa para o qual estava desde sempre destinado. O Estado é um "efeito móvel de governamentalidades múltiplas” (Foucault, 2008a). Como também nos ensina Veena Das (2004), ele se cria e se recria na relação com as margens. Se as milícias se tornaram um dos regimes de fabricação de Estado (Feltran, 2021), o pentecostalismo também se tornou um eixo permanente de governamentalização do mesmo. Estado faz pentecostalismo. Pentecostalismo faz Estado. No âmbito do Legislativo, tem-se a atuação da Frente Parlamentar Evangélica, a ocupação de postos como deputados e senadores federais, deputados estaduais, vereadores e conselheiros municipais; no Executivo, lideranças evangélicas disputam eleições como governadores e prefeitos, assumem postos administrativos como assessores, secretários, ministros, cargos comissionados, e até conselheiros espirituais; ${ }^{7}$ no Judiciário, alcançam visibilidade com a criação da Associação Nacional dos Juristas Evangélicos (ANAJURE), com pautas cristãs e conservadoras, e a presença em cargos como juízes, promotores, procuradores, e até candidatos ao Supremo Tribunal Federal ${ }^{8}$ (Almeida, 2017; Almeida \& Guerreiro, 2021; Vital da Cunha, 2020).

Em artigo recente, Carly Machado (2020)

${ }^{7}$ O pastor Silas Malafaia é a liderança pentecostal da Assembleia de Deus Vitória em Cristo e é o principal porta-voz do governo Bolsonaro nas redes sociais. Seu canal do Youtube tem mais de 1 milhão de seguidores.

${ }^{8} \mathrm{O}$ presidente Jair Bolsonaro indicou o candidato "terrivelmente evangélico" André Mendonça, o atual Advogado-Geral da União, ex-Ministro da Justiça, para ocupar uma vaga no Supremo Tribunal Federal. Link: https:// www1.folha.uol.com.br/poder/2021/07/perto-do-stf-mendonca-virou-o-terrivelmente-evangelico-de-bolsonaro-apos-pregacao-de-reverendo.shtml?origin $=$ folha. Acesso em 20 de outubro de 2021. 
retraçou a trajetória da pastora, cantora gospel, e ex-deputada federal Flordelis, cuja carreira é emblemática, no plano biográfico, do processo de governamentalização do Estado pelos dispositivos pentecostais, das margens ao centro. A partir do "trabalho de base" na baixada fluminense, Flordelis constrói seu percurso missionário e político (os dois termos se tornam indistintos) rumo ao Congresso Nacional. Em torno da controvérsia pública ${ }^{9}$ que se seguiu à suspeita de homicídio do seu próprio marido, a biografia de Flordelis se revestiu com o signo de ignomínia, como se sua história de mulher negra, pobre e periférica, que lutou contra "bandidos" e "juízes" pela adoção dos próprios filhos, estivesse destinada a ter um desfecho trágico. Ao ocupar uma zona cinzenta de indeterminação, entre louca e heroína, Flordelis sintetiza os percursos "mancos" dos sujeitos pentecostais brasileiros ${ }^{10}$. Seus testemunhos de vida e hinos gospel narravam, qual uma profecia autorrealizada, antes mesmo que a suspeição de assassina pesasse sobre os seus ombros, uma história atravessada pela tensão insolúvel entre a "danação" e a "glória", a “queda” e a "redenção" (Machado, 2020).

\section{A INSURREIÇÃO}

Se o bolsonarismo hoje conta com vários "portadores", o presente artigo também o ปิ recorta a partir da perspectiva das margens, ess pecificamente, sob o ângulo do pentecostalisOे mo. Contudo, uma certa dinâmica, que tece os \& fios que compõem um dos diagramas centrais הi do bolsonarismo, parece atravessar classes so$\rightarrow$ ciais e grupos sociais distintos, com sentidos હீ também particulares: a dinâmica da humilha$>$

કิ ${ }^{9}$ Flordelis foi objeto de uma controvérsia recente quando se tornou, em agosto de 2020, a principal suspeita de ser

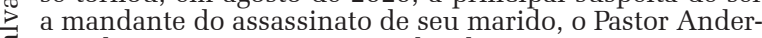
son do Carmo, morto em junho de 2019, com a suposta Ti colaboração de dois dos seus filhos, dos cinquenta e cinco, sendo quatro biológicos e cinquenta e um adotados.

${ }^{10}$ Em um artigo-comentário ao paper de Carly Machado (2020a), propus um debate com o argumento da autora a partir da noção de oikonomia cristã desenvolvida por Giorgio Agamben (2011). ção social, e o desejo de encená-la, repará-la ou vinga-la, por meio de uma insurreição dos bastardos. Em sua posição indecisa no interior da dinâmica das classes sociais, espremida entre a inveja da ostentação dos de cima e o temor pela mobilidade dos de baixo (Nunes, 2021), a "baixa alta classe média" parece compor o quadro dos "bastardos" da própria classe média, pois possuem a renda para serem dignos da situação econômica que gozam mas não detém os signos de distinção daqueles que os "vestem" com a "naturalidade", os que não precisam provar nada para ninguém. Assim, entre os quadros que compõem hoje o staff administrativo, midiático e digital do bolsonarismo, podemos observar sujeitos que tem origem social nessa extração de classe social (não necessariamente vinculados ao pertencimento evangélico), mas também lideranças evangélicas e membros das policiais e milícias (a maioria oriundos das camadas dominadas), e integrantes do mundo industrial, empresarial e financeiro, e outras organizações, como as Forças Armadas. Além do jogo social das classes, algumas pistas teóricas interessantes para pensarmos sobre os "portadores" do bolsonarismo podem ser encontradas na investigação específica da dinâmica própria de cada grupo profissional, o que implicaria na perscrutação minuciosa da posição relacional dos sujeitos dentro de cada campo social (Bourdieu, 1999). O próprio presidente da República, e parte dos quadros do seu staff administrativo, antes de assumir seus postos, encontravam-se em posições heterodoxas ou inconsistentes nos seus respectivos campos (militares, jurídicos, acadêmicos, financeiros, diplomáticos, da indústria do entretenimento, entre outros), vistos por seus pares com um misto de indiferença, desconfiança ou desprezo. Quando se encarregaram de suas novas funções institucionais, romperam com rituais do jogo político, desafiaram hierarquias, zombaram protocolos. ${ }^{11}$ Durante sua carreira ${ }^{11}$ Em Origens do totalitarismo, Hannah Arendt argumenta
que os mais talentosos líderes das massas no totalitarismo
vieram do que ela denomina de "ralé". Segundo ela, "o an-
tigo partido de Hitler" era composto "quase exclusivamen- 
como deputado federal, Bolsonaro construiu sua imagem como o iconoclasta irreverente que desrespeitava performances de respeitabilidade, etiquetas de civilidade e liturgias do cargo. ${ }^{12}$ Os bastardos entraram em cena. ${ }^{13} \mathrm{E}$ farão sua revolução - assim o pretendem.

Em janeiro de 2021, assistimos perplexos a invasão do Capitólio por acólitos de Donald Trump como resposta contra sua derrota nas eleições presidenciais. Em maio de 2020, apoiadores de Bolsonaro fizeram uma carreata em Brasília que solicitava o fechamento do Congresso Nacional e o Supremo Tribunal Federal (STF), com fachas que reivindicavam a intervenção militar. O presidente discursou contra a gestão da pandemia por governadores e prefeitos e cumprimentou o público que se aglomerava de frente ao Palácio da Alvorada. ${ }^{14}$ Um mês antes, em uma reunião com seus ministros, Bolsonaro disse:

Como é fácil impor uma ditadura no Brasil! (...) O povo está dentro de casa. Por isso que eu quero (...)

te de desajustados, fracassados e aventureiros", que não tinham, portanto, nada a perder (Arendt, 2012, p. 367)

${ }^{12}$ Como argumenta Vladimir Safatle, Bolsonaro "expressa uma liderança que parece estar acima da lei, que parece poder falar o que quiser sem culpa, expor os seus piores sentimentos sem preocupação alguma com os efeitos, demonstrar desejos mais baixos de violência como expressão de maior liberdade conquistada" (Safatle, 2018, p.1).

13 Bolsonaro ocupava uma posição "bastarda" no campo das Forças Armadas e também do Congresso Nacional, conhecido por compor o chamado "baixo clero" do Legislativo. Tem com guru ideológico um "bastardo" da academia: Olavo de Carvalho. Nomeia como Ministro das Relações Exteriores alguém que ocupava a ala ideológica que contrariava uma longa tradição da diplomacia brasileira ao se situar no grupo conspiratório e anti-globalista no Itamarati, o Ministro Ernesto Araújo. Indicou como Ministro da Educação Abraham Weintraub, que se situava contra a suposta "doutrinação esquerdista" no interior da universidade. Escolhe como Ministro da Economia Paulo Guedes, que havia obtido um relativo sucesso no management da bolha financeira, mas que não gozava de reconhecimento como profissional na gestão pública. Como Ministra da Mulher, da Família e dos Direitos Humanos, nomeia Damares Alves, uma pastora e advogada que inicia sua carreira política nos conselhos municipais voltados para o direito das crianças e das mulheres; depois atua como assessora parlamentar da Frente Parlamentar Evangélica e contribui com a fundação da Associação Nacional dos Juristas Evangélicos (AnaJure) (Teixeira, 2021, no prelo). No contexto da redemocratização, em uma trajetória política "marginal" no campo dos direitos humanos, Damares, em conjunto com o grupo articulado da direita cristã, passa a disputar a gramática dos direitos humanos, ao redefinir a família heteronormativa como o "princípio ordenador" do seu “ativismo jurídico" (Teixeira, 2021, no prelo).

14 Link do vídeo: https://www.youtube.com/watch?$\mathrm{v}=$ AS5PT-vCFts. Acesso em 12 de fevereiro de 2021 . que o povo se arme, que é a garantia que não vai ter um filho da puta que vai aparecer para impor uma ditadura aqui (...), um bosta de um prefeito, faz um bosta de um decreto, algema, e deixa todo mundo dentro de casa, se tivesse armado, ia para rua (...) É escancarar a questão do armamento aqui. Eu quero todo mundo armado. Que o povo armado jamais será escravizado. ${ }^{15}$

Em um encontro oficial com os principais quadros do seu governo, o presidente incita a insurgência de uma milícia armada - agora por ele autorizada - a praticar a desobediência violenta contra as medidas sanitárias de isolamento social. Há um elemento antiautoritário no fenômeno da nova direita que desconcerta os analistas, pois ela captura uma potência de não identificação com o status quo que pertencia originalmente à esquerda. As mobilizações da sociedade civil que animaram a ascensão das extremas direitas no Brasil e que culminaram na eleição de Jair Bolsonaro em 2018, não podem ser caracterizados simplesmente como conservadorismo ou neoconservadorismo. ${ }^{16} \mathrm{O}$ "desprezo geral pelos padrões morais" (Arendt, 2012, p. 357) revela uma compulsão de destruição própria dos movimentos insurrecionais. A direita se apropriou da dinâmica revolucionária da esquerda, que se viu obrigada a ocupar o discurso da lei e da ordem.

A sanha antiautoritária das novas direitas (que, com certeza, tem componentes próprios que se autonomizaram de uma vinculação diretamente religiosa) dialoga diretamente com o dispositivo antiautoritário do pentecostalismo, que recusa, como vimos, as liturgias

${ }^{15}$ Link do vídeo: https://www.youtube.com/watch?v=D6Jw_GVWu0E. Acesso em 24 de agosto de 2021.

${ }^{16}$ Por motivos de espaço, não posso desenvolver aqui todas as implicacões desse complexo debate. Sobre o "espírito reacionário", o historiador norte-americano Mark Lilla oferece uma análise acurada: "Os reacionários não são conservadores. É a primeira coisa que se deve entender a seu respeito. A sua maneira, são tão radicais quanto os revolucionários e não menos firmemente presos nas garras da imaginação histórica. As expectativas milenaristas de uma nova ordem social redentora e de seres humanos rejuvenescidos inspiram os revolucionários; os reacionários são obcecados pelo medo apocalíptico de entrar numa nova era da escuridão" (2019, p. 11). A respeito do medo de um futuro ameaçador e a nostalgia de um passado destrocado, ver o interessante artigo de Cristina Vital da Cunha sobre a "retórica da perda" no campo pentecostal (2020). 
"autoritárias" do protestantismo ascético, da mídia oficial, do saber científico, ou ainda dos senhorios patronais. A recusa da humilhação dos sujeitos pentecostais se encontra, assim, por cruzamentos ao mesmo estruturantes e conjunturais, com a revolta contra a humilhação do bolsonarismo, que usurpa, com a autoridade dos desautorizados, posições de poder, como se tomassem o Estado por assalto, e arrancassem, por dentro, uma legitimidade que é reivindicada na marra, e se necessário, à bala. Contudo, se as novas direitas podem falar a língua da humilhação (e planejar uma vingança contra ela, que inclui a aniquilação da esquerda) é porque o diagrama da humilhação tem, na história das margens brasileiras, uma sólida sedimentação, cujo fundamento ético-motivacional está ancorado em uma das teodiceias mais poderosas e racionalmente convincentes: o ressentimento do "povo-pária".

Em um dos trechos mais instigantes dos ensaios teórico-reflexivos sobre o impacto das religiões de salvação na história do Ocidente, Max Weber mostra que o ressentimento pode ser um móvel das "éticas religiosas dos negativamente privilegiados", quando surge a "ideia de que a distribuição desigual da sorte na terra tem sua base no pecado e na injustiça dos positivamente privilegiados, o que tem de acarretar, mais cedo ou mais tarde, a vingança divina contra eles" (Weber, 2000, p. 337). Embora possa estar presente em outras 공 religiosidades de camadas dominadas, nunca กิ O ressentimento se revestiu de tanta intensidade como na missão salvífica-messiânica dos judeus. Como "povo-pária” que elabora a ホָ primeira ideia consistente de um deus único, ¿. os judeus aguardavam uma "retribuição" pelo î sofrimento injustamente merecido, o que produz uma relação paradoxal e tensa com o afeto do sofrimento: ao mesmo tempo que o motivo do sofrimento era sentido como infundado e arbitrário, a própria existência do sofrimento era valorizado como tal, pois trazia consigo as dramáticas esperanças de que o desespero (que alcança o paroxismo na teodiceia indivi- dual do Livro de Jó) seria recompensado quando a vingança assolasse os "ímpios". Nas palavras de Weber, "em nenhuma religiosidade do mundo existe um deus universal com a imensa sede de vingança de Jeová” (2000, p. 337). E ainda que o cristianismo dirija suas promessas aos "pobres" e "desvalidos", e contenha traços de "retribuição" no equilíbrio esperado entre o destino pessoal e a reparação divina, a prédica de Jesus Cristo nunca se valeu da centralidade do ressentimento, como se o derradeiro sacrifício do filho de Deus, feito de carne e sangue, pudesse significar uma espécie de "rebelião de escravos na área da moral”, como diz Weber citando Nietzsche (2000, p. 339). Ao contrário, ao fundar o universalismo da graça do "cordeiro de Deus que lava os pecados do mundo", o cristianismo rompe, de uma vez por todas, com a ideia particular de um povo-eleito, que deve ser recompensado justamente por ser pária. Ao romper com a ideia de "dupla moral" dos judeus - uma interna para seu grupo étnico, outra externa para estrangeiros -, o cristianismo cria o "acosmismo do amor sem objeto" (Weber, 1982, p. 379), no sentido de um fraternidade universal, o que torna vão, e no limite, sem qualquer propósito, "precisamente o ressentimento típico e profundo do povo-pária" (2000, p. 339). A partir desse trecho da obra de Weber, podemos entrever certos insights teóricos para pensar as razões pelas quais o pentecostalismo é uma ética de salvação voltada particularmente para o Velho-Testamento, no qual se observa, por vezes, o silêncio da conclamação profética de Jesus Cristo dirigida à humanidade como um todo (não a um povo eleito). A ética "velho-testamentária”, expressa por vezes na rigidez moralista, e sem solução de compromisso, da lei mosaica, estende-se para além do próprio pertencimento ao pentecostalismo, e espraia-se como um código difuso das margens, como observa-se no senso de justiça das facções criminais (Feltran, 2021). A imaginação teológica sobre a condição de pária, uma condição em si mesma "bastarda", é necessária para que se mobilize, de forma ain- 
da mais dura, o ressentimento dos humilhados - e a espera de reparação em uma guerra divina contra os impuros (que podem assumir, como vimos, várias figurações). É por isso que a divindade preponderante nas periferias brasileiras, e talvez a única capaz de traduzir a violência inscrita nessas experiências de mundo, não é o "Deus do Amor", mas o "Deus dos Exércitos". O horizonte de "retribuição", na expectativa profética de que os "humilhados serão exaltados", é expressa na "revelação" do pastor Silas Malafaia, em um dos cultos da sua denominação, ao lado de Jair Bolsonaro, poucos dias depois da vitória no segundo turno das eleições de 2018. Ainda que a passagem bíblica escolhida pertença ao Novo Testamento, o chamado ao calvário de Cristo que redime todos os homens, propagado por São Paulo, ganha aqui o contorno da escolha de um messias - no caso, Bolsonaro - para assumir a tarefa da vingança para um povo eleito, o que recupera a ideia de "casta-pária", que teria sido eliminada justamente na profecia cristã: ${ }^{17}$

Deus escolheu as coisas loucas para confundir as sábias, Deus escolheu as coisas fracas para confundir as fortes. Agora a coisa vai ser mais profunda. Deus escolheu as coisas vis, de pouco valor. As desprezíveis, que podem ser descartadas. As que não são, que ninguém dá importância, para confundir as que são, para que nenhuma carne para carne se glorie diante Dele. É por isso que Deus te escolheu. ${ }^{18}$

\section{CONSIDERAÇÕES FINAIS}

Parte das ciências sociais brasileiras assistiu a ascensão das novas direitas no Brasil contemporâneo e a vitória do candidato Jair Bolsonaro nas eleições de 2018 com um misto

\footnotetext{
${ }_{17}$ A fala de Malafaia remete a passagem bíblica de Coríntios 1: 27-29. Agradeço a Bruno Cruz, meu querido ex-aluno e amigo, que contribuiu com essa reflexão ao oferecer esclarecimentos sobre essa passagem em particular, quando Paulo prega aos coríntios dizendo que a "loucura" da crucificação de Cristo, incompreensível e escandalosa para judeus e pagãos, é justamente o que comporta a "sabedoria” da possibilidade de redenção universal.

${ }^{18}$ Link do vídeo: https://www.youtube.com/watch?v=E4E58Wz0XHQ. Acesso em 10 de outubro de 2021.
}

de perplexidade e torpor. Durante os trinta anos da nova república nunca a opção eleitoral da extrema direita havia conquistado um número expressivo de votos. A eleição de Bolsonaro parecia, para muitos, resultado de um desvio histórico ou de uma histeria coletiva fomentada pela enxurrada de notícias falsas. Contudo, o bolsonarismo não é um "erro" na nossa história democrática. Ao contrário, ele é a expressão mais bem-acabada - e nesse sentido, mais coerente-dos experimentos biopolíticos (Foucault, 2000) e necropolíticos (Mbembe, 2018) que o precederam e que, de alguma maneira, o prepararam. Assim, para além da tese da manipulação produzida pela mídia oficial e/ou fabricada pelas fake news espalhadas pelas redes sociais, é preciso admitir a hipótese de que a campanha eleitoral da extrema-direita obteve sucesso não porque manipulou sujeitos suscetíveis à uma propaganda ardilosa, mas porque foi capaz de nomear o inominável de uma violência insidiosamente experimentada nas margens. Compreender a virada do neoliberalismo autoritário à brasileira passa pelo desafio de investigar quais são os portadores do bolsonarismo. Embora frações da classe média e da elite tenham embarcado nesse jogo social a partir de 2013, as modalidades de governo da administração Bolsonaro, e os movimentos civis que a sustentam, se assentam em dispositivos que haviam sido experimentados nas margens há pelo menos três décadas: o pentecostalismo e as milícias. Como "bastardos" pobres e pretos do protestantismo branco e rico, o movimento pentecostal ofereceu um diagrama simbólico para que os sujeitos periféricos pensassem seus lugares no mundo social, como classe, raça e gênero. Desde a década de 1990, para além de fomentar uma remagificação do religioso, o pentecostalismo criava e recriava modalidades inventivas e plásticas de condução das condutas dos indivíduos nas margens. O diagrama da guerra, a narrativa da humilhação, a recusa da autoridade, o empreendedorismo periférico compunha tecnologias de governo do outro e de si. Mais tarde, esses dispositivos ofereceram eixos de governamen- 
talização do próprio Estado, em um movimento das margens ao centro. Estavam assentadas as bases para que se produzisse uma insurreição dos humilhados, segundo a perspectiva de que a "reparação" pela humilhação não poderia mais ser aguardada na transcendência de outra vida ou no messianismo de outro tempo, mas teria que ser executada já, em uma batalha violenta (se necessário, armada) contra aqueles que ameaçam a existência dos "justos". O governo Bolsonaro nunca prometeu entregar um programa político concreto, mas sempre se anunciou como aquele que gere a catástrofe por ele mesmo criada, como se fosse necessário precipitar o fim da história e fabricar uma calamidade ainda maior como pretexto de combate à calamidade que ele pretende dizimar: a suposta degeneração dos valores pela esquerda ${ }^{19}$. A sua pulsão apocalíptica parte da premissa de que a agenda "corrupta" e "degenerada" da Nova República deve ser passada a limpo em nome de um empreendimento ousado o suficiente para realizar apenas o que os "fortes" são capazes: romper com as organizações democráticas por meio de uma catarse purificadora e redentora - "ir contra tudo que isso que está aí", como o presidente sempre diz em seu discurso grandiloquente e vazio. $\mathrm{O}$ artigo pretendeu contribuir com o esforço genealógico sobre como chegamos até aqui. Resta saber se teremos a coragem necessária para encarar o monstro subterrâneo que finalmente deu as caras, mas que sempre స్

Recebido para publicação em 18 de setembro de 2021 Aceito em 08 de novembro de 2021

\section{REFERÊNCIAS}

ABÍLIO, Ludmila Costhek. Uberização: a era do trabalhador just-in-time? Estudos Avançados 34 (98), p.111-126, 2020.

ABREU, Nayara. "Magia" neopentecostal e "espírito" neoliberal. 2017. Dissertação (Mestrado em Ciências

${ }^{19}$ Esse argumento dialoga com uma palestra ministrada por Paulo Arantes. Link do vídeo: https://www.youtube. $\mathrm{com} /$ watch $? \mathrm{v}=\mathrm{McSgNKEJoDg \& t}=5750 \mathrm{~s}$. Acesso dia $30 \mathrm{de}$ setembro de 2021.
Sociais) - Programa de Pós-Graduação em Ciências Sociais da Universidade Federal de Uberlândia - UFU.

AGAMBEN, Giorgio. O resta d'Auschwitz. São Paulo: Boitempo, 2008.

AGAMBEN, Giorgio. O que é contemporâneo? E outros ensaios. Chapecó: Argos, 2009.

AGAMBEN, Giorgio. O reino e a glória: Uma genealogia teológica da economia e do governo. São Paulo: Boitempo, 2011.

ALMEIDA, Ronaldo. A Igreja Universal e seus demônios: um estudo etnográfico. São Paulo: Terceiro Nome, 2009.

ALMEIDA, Ronaldo. Pluralismo religioso e espaço metropolitano. In: ALMEIDA, Ronaldo \& MAFRA, Clara (orgs.). Religiões \& Cidades: Rio de Janeiro e São Paulo. São Paulo: Terceiro Nome, 2009.

ALMEIDA, Ronaldo. A onda quebrada - Evangélicos e conservadorismo. Cadernos Pagu, (50), 2017, p. 1-27.

ALMEIDA, Ronaldo.; GUERREIRO, Clayton. Negacionismo religioso: Bolsonaro e lideranças evangélicas na pandemia Covid-19. Religião \& Sociedade, Rio de Janeiro, 41 (2); 2021, p. 49-73.

ANDRADE, D.; CÔRTES, M.; ALMEIDA, S. Neoliberalismo autoritário no Brasil. Caderno CRH, Salvador, v. 34, [2021]. No prelo.

ANDRADE, Daniel Pereira. O que é o neoliberalismo? A renovação do debate nas ciências sociais. Sociedade \& Estado, 34 (1), p. 211-239, 2019 a.

ANDRADE, Daniel Pereira. Neoliberalismo: crise econômica, crise da representatividade democrática e reforço da governamentalidade. Novos Estudos Cebrap, 38 (1), p. 109-135, 2019b.

ARENDT, Hannah. Origens do totalitarismo. São Paulo: Companhia das Letras, 2012.

BOURDIEU, Pierre. A economia das trocas simbólicas. São Paulo: Perspectiva, 1999.

BOURDIEU, Pierre. Meditações pascalianas. Rio de Janeiro: Bertrand Brasil, 2001.

BROWN, Wendy. Cidadania sacrificial: Neoliberalismo, capital humano e políticas de austeridade. Rio de Janeiro: Zazie Edições, 2018.

CAMPOS, Leonildo Silveira. Teatro, templo e mercado. São Paulo: Vozes, 1997.

CÔRTES, Mariana. O bandido que virou pregador. São Paulo: Hucitec, 2007.

CÔRTES, Mariana. Diabo e fluoxetina: Pentecostalismo e psiquiatria na gestão da diferença. Curitiba: Appris, 2017.

CÔRTES, Mariana; JARDIM, Fabiana; MIAGUSKO, Edson. Governo, gestão de populações e subjetividades: balanço e perspectivas analíticas. Revista Brasileira de Sociologia, vol. 06, no. 12, Jan-Abri/2018, p. 242-265.

CÔRTES, Mariana. Entre a danação e a glória: O ministério de Flordelis e o problema da oiknomia cristã. Debates do NER, Porto Alegre, ano 20, n. 38, ago./dez. 2020a, p. 83-95.

CÔRTES, Mariana. A nova ascese do capitalismo contemporâneo. In: SENEDA, Marcos César; CUSTÓDIO, Henrique Florentino Faria (orgs.). Ciência como vocação: Racionalidades e irracionalidade no Velho e no Novo Mundo. Porto Alegre: Editora Fi, 2020b.

CÔRTES, Mariana; TEIXEIRA, Jacqueline Moraes. (PREPRINT) Pandemic and Pentecostalism in Brazil: Religion, Politics, And Sanitary Measures in Dispute. Religion and Pandemic: Shifts in Interpretations, Popular Lore, and Practices. Vol. 12, No. 3. EntangledReligions. RuhrUniversität Bochum, 2021. Link: https://er.ceres. rub.de/index.php/ER/article/view/9262/8800. Acesso em 10.10.2021. 
DARDOT, Pierre; LAVAL, Christian. A nova razão do mundo: Ensaio sobre a sociedade neoliberal. São Paulo: Boitempo, 2016.

DAS, Veena. Anthropology in the Margins of the State. Santa Fe: School of American Research Press, 2004.

DAS, Veena. Textures of the Ordinary: Doing Anthropology after Wittgenstein. New York: Fordham University Press, 2020

FELTRAN, Gabriel. Fronteiras de tensão: Política e violência nas periferias de São Paulo. São Paulo: Editora Unesp, 2011.

FELTRAN, Gabriel. Valor dos pobres: A aposta do dinheiro como mediação para o conflito social contemporâneo. Cadernos CRH, vol. 27, p. 495-512, 2014.

FELTRAN, Gabriel. Formas elementares da vida política: Sobre o movimento totalitário no Brasil (2013-). Blog Novos Estudos Cebrap. 2020. Disponível em: http:// novosestudos.com.br/formas-elementares-da-vidapolitica-sobre-o-movimento-totalitario-no-brasil-2013/. Acesso em 20.08.2021.

FELTRAN, Gabriel. Polícia e política: O regime de poder hoje liderado por Bolsonaro. Blog Novos Estudos Cebrap. 2021. Disponível em: http://novosestudos.com.br/ policia-e-politica-o-regime-de-poder-hoje-liderado-porbolsonaro/. Acesso em 20.08.2021.

FOUCAULT, Michel. Em defesa da sociedade. São Paulo: Martins Fontes, 2000.

FOUCAULT, Michel. Segurança, território e população. São Paulo: Martins Fontes, 2008a.

FOUCAULT, Michel. Nascimento da biopolítica. São Paulo: Martins Fontes, 2008b.

GUTIERREZ, Carlos Andrade Rivaz. A reflexividade evangélica a partir da produção crítica e construção de projetos de vida na Igreja Universal do Reino de Deus. 2017. Tese (Doutorado em Antropologia Social) - Programa de Pós-Graduação em Antropologia Social - Faculdade de Filosofia e Ciências Humanas da Universidade Estadual de Campinas.

JARDIM, Fabiana. Entre o desalento e a invenção. São Paulo: Editora Annablume, 2009.

LILLA, Mark. A mente naufragada: Sobre o espírito reacionário. Rio de Janeiro; São Paulo: Record, 2018.

MACHADO, Carly Barbosa. Pentecostalismo e o sofrimento do (ex-) bandido: Testemunhos, mediações, modos de subjetivação e projetos de cidadania nas periferias. Horizontes Antropológicos, Porto Alegre, ano 20, n. 42, p. 153-180, jul./dez. 2014.

MACHADO, Carly Barbosa. Desafios políticos, etnográficos e conceituais: Uma conversa sobre e a partir do Ministério Flordelis e seus congressos. Debates do NER, Porto Alegre, ano 20, n. 34, ago/dez. 2020, p. 115-133.

MACHADO DA SILVA, Luiz Antônio. Vida sob certo: Violência e rotina nas favelas do Rio de Janeiro. Rio de Janeiro: Nova Fronteira, 2008.

MAFRA, Clara. Drogas e símbolos: redes de solidariedade em contextos de violência. In: ZALUAR, Alba; ALVITO, Marcos (orgs). Um século de favela. Rio de Janeiro: Editora FGV, 2006.

MAFRA, Clara. O problema da formação do "cinturão pentecostal” em uma metrópole da América do Sul. Interseções [Rio de Janeiro], v. 13, n. 1, p. 136-152, jun. 2011.

MANSO, Bruno Paes. A república das milícias. Dos esquadrões da morte à era Bolsonaro. São Paulo: Todavia, 2020.

MARIANO, Ricardo. Neopentecostais: Sociologia do novo pentecostalismo no Brasil. São Paulo: Loyola, 1999.

ONG, Aishwa. Neoliberalism as exception. Mutations in citizenship and sovereignty. London Duke University Press, 2006.

MBEMBE, Achille. Necropolítica. São Paulo: N-1 Edições, 2018.

NUNES, Rodrigo. Pequenos fascismos, grandes negócios: O bolsonarismo como empreendedorismo - e o que isso diz sobre a natureza da direita e do capitalismo hoje. Revista Piauí, Edição 181, outubro de 2021. Disponível em: https://piaui.folha.uol.com.br/materia/pequenosfascismos-grandes-negocios/. Acesso em 25.10.2021.

ONG, Aishwa. Neoliberalism as exception. Mutations in citizenship and sovereignty. London: Duke University Press, 2006

PINHEIRO-MACHADO, R.; SCALCO, L. Da esperanca ao ódio: Juventude, política e pobreza do lulismo ao bolsonarismo. Revista IHU On-Line, 04/10/2018. Disponível em http://www.ihu.unisinos.br/78-noticias/583354-daesperanca-ao-odio-juventude-politica-e-pobreza-do-lulismoao-bolsonarismo. Acesso em: 30 de outubro de 2021.

PINHEIRO-MACHADO, R.; SCALCO, L. From hope to hate: The rise of conservative subjectivity in Brazil. HAU: Journal of Ethnographic Theory, 10 (1), spring 2020.

PIERUCCI, Antônio Flávio; PRANDI, Reginaldo. A realidade social das religiões no Brasil. São Paulo: Hucitec, 1996.

SADER, Eder. Quando novos personagens entraram em cena: experiências, falas e lutas dos trabalhadores da Grande São Paulo, 1970-1980. 4ª . Ed. Rio de Janeiro: Paz e Terra, 2001.

SANT'ANA, Raque. A nação cujo Deus é o Senhor: A imaginação de uma coletividade "evangélica” a partir da Marcha para Jesus. 2017. Tese (Doutorado em Antropologia Social) - Programa de Pós-Graduação em Antropologia social, Museu Nacional, Universidade Federal do Rio de Janeiro.

SAFLATLE, Vladimir. O que é fascismo? Revista Cult. 22 de outubro de 2018. Disponível em: https://revistacult.uol. com.br/home/o-que-e-fascismo/. Acesso em 02.10.2021.

SENNA, Luciano; SWATOWISKI, Cláudia. Pentecostais em movimento de moradia: O caso da "Ocupação do Glória” em Uberlândia (MG). Revista Religião e Sociedade, Rio de Janeiro, 39(2), p. 152-174, 2019.

SOUZA, Jessé. Os batalhadores brasileiros: Nova classe média ou nova classe trabalhadora? Belo Horizonte: UFMG, 2012

TEIXEIRA, Jacqueline Moraes. A conduta universal governo de si e políticas de gênero na Igreja Universal do Reino de Deus. 2018. Tese (Doutorado em Antropologia Social) - Programa de Pós-Graduação em Antropologia Social da Faculdade de Filosofia, Letras e Ciências Humanas da Universidade de São Paulo.

TEIXEIRA, Jacqueline Moraes. Gender, family, and the dispute on the Human Rights grammar in Brazil (no prelo).

TELLES, Vera da Silva. A cidade nas fronteiras do legal e do ilegal. Argvmentvm Ed.: Belo Horizonte, 2010.

VIANA, Silvia. Rituais de sofrimento. São Paulo: Boitempo, 2014.

VITAL DA CUNHA, Christina. Oração de traficante. Rio de Janeiro: Garamond, 2015

VITAL DA CUNHA, Christina. Retórica da Perda nas eleições presidenciais brasileiras em 2018: religião, medos sociais e tradição em foco. Plural. Antropologías desde América Latina y el Caribe, Año 3, nol. 6, Julio-Diciembre, 2020, p. 123-149.

WEBER, Max. Ensaios de Sociologia. Rio de Janeiro: Editora Guanabara Koogan, 1982.

WEBER, Max. Economia e sociedade: fundamentos da sociologia compreensiva. $3^{\mathrm{a}}$. Ed. Brasília: Editora Universidade de Brasília, 2000 


\section{THE REVOLT OF THE BASTARDS: from Pentecostalism to "Bolsonarismo"}

\section{Mariana Côrtes}

The article intends to offer a theoreticalmethodological contribution to the debate on authoritarian neoliberalism, from the perspective of the margins, more specifically, of the Pentecostal movement. By tracing a genealogy of the expansion of Pentecostalism during the three decades of the New Republic, the text argues that some dimensions present in the Brazilian authoritarian turn were gestated in Pentecostal agencies, such as the war diagram, the refusal of humiliation, the anti-authority device and the grammar of entrepreneurship. The central thesis is that Pentecostalism and "Bolsonarismo" can be described as a revolt of the "bastards". From the margins to the State, it is intended to analyze how a contestation of peripheral subjects who occupy "ambiguous" positions within the religious field has a connection with a conservative insurrection, which aims to reach institutional positions in the legislative, executive and judiciary powers, from subjects that occupied heterodox positions in various fields of action, such as legal, political, military, academic.

KEY-wORDS: Authoritarian neoliberalism. Pentecostalism. "Bolsonarismo". Refusal of humiliation. Bastards.

\section{LE RÉVOLT DE BÂTARDS: du Pentecôtisme au "Bolsonarismo"}

\section{Mariana Côrtes}

Larticle entend offrir une contribution théorique et méthodologique au débat sur le néolibéralisme autoritaire, du point de vue des marges, plus spécifiquement, du movement pentecôtiste. En retraçant une généalogie de l'expansion du pentecôtisme au cours des trois décennies de la Nouvelle République, le texte soutient que certaines dimensions trouvées dans le tournant autoritaire brésilien ont été en gestation dans les agences pentecôtistes, telles que le diagramme de guerre, le refus de l'humiliation, le dispositif anti-autorité et la grammaire de l'entrepreneuriat. La thèse centrale est que le pentecôtisme et le "bolsonarismo" peuvent être décrits comme une révolte des "Bâtards". Depuis les marges de l'État, il s'agit d'analyser comment une contestation d'individus périphériques qui occupent des positions "ambiguës" dans le champ religieux s'articule avec une insurrection conservatrice, qui veut atteindre des positions institutionnelles dans les pouvoirs législatif, exécutif et judiciaire, de sujets qui occupaient despositions hétérodoxes dans divers domaines d'action, tels que juridique, politique, militaire, universitaire.

Mot-CLÉs: Néoliberalism autoritaire. Pentecôtisme. "Bolsonarismo". Refus de l'humiliation. Bâtards. Professora do Instituto de Ciências Sociais e do Programa de Pós-Graduação em Ciências Sociais da Universidade Federal de Uberlândia. Coordenadora do Travessias - Grupo de Pesquisas Urbanas. Realizou estágio-doutoral na École des Hautes Études en Sciences Sociales, Paris, França (2009). Tem experiência na área de Sociologia, atuando nos seguintes temas: teoria sociológica; religião; violência; neoliberalismo; psiquiatria; sofrimento. É autora dos livros O bandido que virou pregador: A conversão de criminosos ao pentecostalismo e suas carreiras de pregadores (2007) e Diabo e fluoxetina: Pentecostalismo e Psiquiatria na gestão da diferença. 2017. 